\title{
Executive pay and performance: did bankers' bonuses cause the crisis?
}

Article

Accepted Version

Gregg, P., Jewell, S. and Tonks, I. (2012) Executive pay and performance: did bankers' bonuses cause the crisis? International Review of Finance, 12 (1). pp. 89-122. ISSN 1468-2443 doi: https://doi.org/10.1111/j.1468-

2443.2011.01136.x Available at https://centaur.reading.ac.uk/24831/

It is advisable to refer to the publisher's version if you intend to cite from the work. See Guidance on citing.

To link to this article DOI: http://dx.doi.org/10.1111/j.1468-2443.2011.01136.x Publisher: Wiley

All outputs in CentAUR are protected by Intellectual Property Rights law, including copyright law. Copyright and IPR is retained by the creators or other copyright holders. Terms and conditions for use of this material are defined in the End User Agreement.

\section{www.reading.ac.uk/centaur}

\section{CentAUR}

Central Archive at the University of Reading 
Reading's research outputs online 


\title{
Executive Pay and Performance:
}

\section{Did Bankers' Bonuses Cause the Crisis?}

\author{
By \\ Paul Gregg \\ CMPO \\ University of Bristol \\ P.Gregg@bristol.ac.uk \\ Sarah Jewell \\ University of Reading \\ S.L.Jewell@ reading.ac.uk \\ and \\ Ian Tonks \\ School of Management \\ University of Bath \\ I.Tonks@ bath.ac.uk
}

July 2011

Contact Author: Ian Tonks, School of Management, University of Bath, Bath, BA2 7AY, United Kingdom; Tel. 01225-384842.

This paper has benefited from comments made at seminar presentations at the Universities of Amsterdam, Bristol, CASS Business School, Exeter, Leeds, Oxford, Reading and the Asian Finance Association, HKUST June 2010. We are particularly grateful to Renee Adams (the editor), Thomas Kirchmaier and an anonymous referee for comments on an earlier draft. We are also very grateful to Maria Michou and Rajesh Tharyan for help in updating the data used in this study. 


\title{
Executive Pay and Performance:
}

\section{Did Bankers' Bonuses Cause the Crisis?}

\begin{abstract}
This paper examines the pay-performance relationship between executive cash compensation (including bonuses) and company performance for a sample of large UK companies, focusing in particular on the financial services industry, since incentive misalignment has been blamed as one of the factors causing the global financial crisis of 2007/08. Although we find that pay in the financial services sector is high, the cash-plus-bonus pay-performance sensitivity of financial firms is not significantly higher than in other sectors. Consequently, we conclude that it unlikely that incentive structures could be held responsible for inducing bank executives to focus on short-term results.
\end{abstract}

Keywords: Executive compensation, pay and performance, incentives JEL Classification: G34, J33, M52 
The global banking crisis of 2007-08 has been partly blamed on remuneration policies in financial institutions. According to Turner (2009) "There is a strong prima facie case that inappropriate incentive structures played a role in encouraging behaviour which contributed to the financial crisis" (p. 79). In this paper we evaluate this claim by examining the pay-performance relationship of executives in all UK companies, and in financial services companies in particular. ${ }^{1} \mathrm{We}$ argue that if an emphasis on short-term profits in the banking sector meant that remuneration structures in banks and financial services were to blame for the crisis, we would expect to find evidence that prior to the crisis pay-performance sensitivities were higher in the financial services sector than in other sectors. We show that base pay compensation and bonuses of all UK executives increased substantially over the period 1994-2006, and we provide evidence on the movement in the pay-performance sensitivity over time. We find that pay in the financial services sector is high. But, contrary to the prediction that pay was over-sensitive to short-term profits, we find that the pay-performance sensitivity of banks is not significantly higher than in other sectors, and is generally quite low. We therefore question how incentive structures in banks could be blamed for the crisis since there is little evidence that executive compensation in the banking sector depended on short-term financial performance. However, across firms in all sectors we do identify an intriguing asymmetric relationship between pay and performance: when stock returns are high, pay-performance elasticities are also relatively high, but we find that executive pay is less sensitive to performance when stock returns are low. Again, this is a result that we find applies to all firms, not just firms in the financial sector.

A number of recent papers have investigated whether the performance of US banks during the financial crisis was related to executive incentives before the crisis. Fahlenbrach and Stulz (2010) suggest that perverse incentives are dampened if the interests of executives and shareholders are aligned through executives' ownership of company stock. They find no evidence that banks with CEOs whose incentives were less well aligned with the interests of their shareholders performed worse during the

\footnotetext{
${ }^{1}$ FSA (2009a) suggests that "further research to establish correlations between remuneration practices (good and bad) and performance could be interesting and worthwhile" (Paragraph 3.3)
} 
crisis. Conyon, et al (2010) show that the role of compensation in promoting excessive risk taking prior to the crisis was dwarfed by the roles of loose monetary policy, social housing policies, and financial innovation. Adams (2009) documents that the governance of S\&P financial firms is no worse than in S\&P non-financial firms, and that US banks receiving bailout money had boards that were more independent than in other banks.

What is the evidence from countries other than the US? Beltratti and Stulz (2010) in a cross-country comparison of the performance of banks during the financial crisis, find that it was the fragility of banks' balance sheets, and in particular their reliance on short-term capital market funding, that explained their poor performance. Erkens, Hung and Matos (2009) examine corporate governance policies in 306 financial institutions across 31 countries during the credit crisis. In contrast to the evidence for US banks, they find that financial firms that used CEO compensation contracts with a heavier emphasis on non-equity incentives (bonuses) rather than equity-based compensation) performed worse during the crisis and took more risk before the crisis. Our paper contributes to this literature by examining the sensitivity of executive compensation to corporate performance in UK financial firms compared to UK nonfinancial firms prior to the financial crisis.

Following on from the Turner Report, UK policy makers have been at the forefront of moves to establish a regulatory framework that ensures the structure of executive remuneration arrangements is appropriate for the risk-management of financial institutions. The Walker Report (2009a, 2009b), in tandem with the UK's regulator in FSA (2009a, 2009b), analysed the problems with executive remuneration structures in the financial services sector and recommended a number of changes to compensation practices.

Prior to the credit crisis, the UK's Corporate Governance Code provided requirements on the role of remuneration committees in setting the level and structure of remuneration for executives. The Code enshrined a number of recommendations that arose out of a series of corporate governance reports throughout the nineteen nineties. These recommendations included: splitting the roles of chairman and chief executive (Cadbury, 1992), disclosure of executive pay, establishment of remuneration and audit 
committees, and linking executive incentive pay to clear performance criteria (Greenbury, 1995), the numbers and responsibilities of non-executive directors on the board (Hampel, 1998), internal control mechanisms and risk management (Turnbull, 1999), and independence of non-executives (Higgs, 2003). The requirements in the Code are applied through the Listing Rules in the FSA Handbook. However, Walker (2009a) recognised that remuneration structures governed by the Code had been deficient, and "had been inconsistent with sound risk management by giving employees incentives to pursue risky policies and in effect undermine the firm's own systems designed to control risk." (Paragraph 7.3)

FSA (2009a) identified potential market failures in the structures of remuneration practices in financial services, and suggested that an emphasis on short-term profits by institutional investors had encouraged executive remuneration to be focused on "variable compensation" (bonuses) related to the most recent earnings, without any consideration of the exposure to risk-taking. In addition variable compensation schemes tend to be pro-cyclical, since down-side bonuses are capped at zero. These practices were sustained by pressures in the labour market and weak remuneration committees. In response to these perceived market failures, Walker (2009b) recommended a series of changes to remuneration practices: alignment of compensation and its risks made the responsibility of remuneration committees; transparency of the process and levels of executive pay; deferral of incentive payments; and performance criteria related to long-term profitability. These recommendations and eight key principles on executive remuneration identified in FSA (2009b) were enacted in an updated code for UK banks and building societies that became effective from January 2010 .

At the international level remuneration policy has been taken forward through two main channels - the Financial Stability Forum (FSF) and the Committee of European Banking Supervisors (CEBS). FSF (2009) contains a set of principles for sound compensation practices, with similar themes to the Walker Report, and was released at the G20 summit meeting in London (subsequently renamed the Financial Stability Board (FSB)). In drawing up future regulations for European banks, CEBS (2009, 2010) suggest a similar set of remuneration policies, and the European Commission (2009) published draft amendments to the Capital Requirements Directive (CRD) 
which include comparable provisions on remuneration. FSA (2009b) notes that proposals consistent with the principles in FRF (2009) are being considered in Australia, France, the Netherlands, Switzerland, and the US. FSA (2010) lists the revisions to the UK's Remuneration Code which took effect from January 2011, and are consistent with the recommendations in CRD3, ensuring an alignment of remuneration principles across the EU. But FSA (2010) notes that in contrast outside of the EU, some G20 countries have implemented the FSB Principles on the basis of guidance rather than as enforceable rules. These differences and the lack of a level playing field may cause problems in the future for EU-based banks competing in nonEU markets.

Fahlenbrach and Stulz (2010) suggest that there are a range of alternative transmission mechanisms that might explain the misalignment of incentives and the credit crisis. The version emphasised in FSA (2009a) is that executive pay was too sensitive to short-term profits. But this is a testable relationship which we will examine in this paper. The empirical relationship between executive pay and performance starts from the influential study by Jensen and Murphy (1990), who first identified the payperformance puzzle: that there is little relationship between these variables. For UK firms, Conyon et al (1995), Main et al (1996), Conyon (1997) and Benito and Conyon (1999) confirmed these low pay-performance sensitivities (PPS), with typical elasticities of around 0.15. Fernandes at al (2010) report that the positive relationship between CEO pay and firm size documented in the U.S. is pervasive across all countries, although the pay-size elasticity is higher in the U.S. than elsewhere. In a comparison of US and UK firms, Conyon and Murphy (2000) found a pay-size relationship of 0.32 for US firms and 0.2 for UK firms.

Murphy (1999) draws a distinction between cash compensation, which includes base salary and annual bonuses (non-equity incentives), and total compensation, which adds in equity incentives such as stock options and LTIPS. The early UK literature related only to cash compensation due to the difficulty of obtaining information on equity incentive based compensation up to 1997 , when disclosure rules prompted by Greenbury (1995) came into effect. The inclusion of equity incentive payments (Main et al, 1996; Buck et al, 2003; Ozkan, 2010) increases pay-performance sensitivities. Buck et al (2003) argue that LTIPs should be included in the estimation of pay- 
performance sensitivities, but recognise that including LTIPs and share options will have a "mechanical relation to performance conditions". Conyon and Murphy (2000, Table 1) document that in the 1997 fiscal year UK CEOs' total compensation was made up of: base salary and pensions 64\%, equity-based (options and LTIPs) incentive plans 19\%, and bonuses $18 \%$. They also reported that the use of equitybased incentives at that time was less prevalent in the financial services sector than other industries, comprising only $13 \%$ of the executives' pay packages (35\% for allincentive pay). More recently Fernandes et al (2010, Table 1) has undertaken an international comparison of CEO pay and reports that in the UK, salary and pensions constituted $51 \%$ of the total compensation package in the year 2006, with equity incentives comprising 30\% and bonuses, 19\%. This suggests that over the period 1997-2006 there has been a decline in the importance of base salaries and an increase in the percentage of equity-based incentive pay for executives.

\section{[INSERT EXHIBIT 1 ABOUT HERE]}

In order to provide further evidence on these trends in Exhibit 1 we have collected data on non-incentive pay and incentive pay (both equity and non-equity) for a subsample of FTSE100 firms in the banking and non-banking sectors from the sample used in this study. In the table we have identified the total compensation for four banks and four comparable non-banks (that are also constituents of the FTSE100 Index with a distribution of total compensation of the board in 2000 that spans the distribution of the four banks). We show the percentage of non-incentive pay (base salary plus other), equity incentive pay (options and LTIPs) and non-equity incentive pay (bonuses) for each company between two years 2000 and 2006. Focusing on the average row for each panel, we can see that there is little difference between the banking and non-banking sectors in terms of the percentages of each component of pay. For the total board pay, base pay constitutes around 40 per cent of total compensation in 2000, and had fallen to around 27 per cent by 2006. Bonuses (nonequity incentives) increased to almost 30 per cent of compensation in the banking sector by 2006, and to 20 per cent in non-banking firms. Equity incentive pay in both banking and non-banking remained fairly constant at around 45 per cent of total pay. It is also clear that there are substantial differences in the components of pay within industries. For example Barclays paid out 38.2 per cent of total board pay in the form 
of bonuses, whereas HSBC put much greater reliance on basic salary at 38.6 per cent. The numbers in Exhibit 1 suggest that base salary is lower and incentive pay (both equity and non-equity) is higher for our sub-sample than the components identified in Fernandes et al (2010), and is consistent with their funding that larger firms tend to make greater use of incentive compensation.

In the current paper, we focus on executive pay-performance sensitivity with respect to cash compensation including base salary and non-equity bonuses, and we report below that the growth in this cash compensation for UK directors is well above the level of inflation and wage growth. It is the non-equity incentive payments, which were paid on the basis of past short-term profits, that have been most heavily criticised by regulators (Walker, 2009a, 2009b; FSA, 2009), as not being related to long-term profitability. ${ }^{2}$

There is conflicting evidence as to whether the pay-performance relationship has weakened or strengthened over time. Jensen and Murphy (1990) for the US and Gregg et al (1993) for the UK suggested the pay-performance relationship had weakened; but in contrast Hall and Liebman (1998) and Benito and Conyon (1999) found it had increased. Over time corporate governance practices change, and Bertrand and Mullainathan (2001) suggest that firms with stronger corporate governance structures tend to have higher pay-performance sensitivities. However in the UK Conyon (1997), Benito and Conyon (1999), Girma, Thomson and Wright (2007) and Ozkan (2010) have all found little evidence of various corporate governance changes affecting the level and structure of CEO pay. A contribution of the current paper is to assess the movement in the pay-performance relationship from the mid-nineties onwards.

Jensen and Murphy (1990) reported little evidence that relative performance to other firms in the same industry acted as a yardstick to managerial incentives. In contrast, Gibbons and Murphy (1990) established that both industry and market relative

\footnotetext{
${ }^{2}$ These policy documents downplay the role of equity-based compensation schemes (share options and LTIPs) as being problematic, since the policy recommendations under discussion is that incentive compensation schemes in the future should be more equity-based: aligning the interests of executives and shareholders.
} 
performance played an important role in shaping executive pay. They found that market performance had a stronger effect than relative industry performance using a large sample of 9,425 firm years over the period 1974 to 1984. Previous UK studies that have explored relative performance evaluation (Main et al, 1996; Benito and Conyon, 1999) found insignificant results.

Argarwal and Samwick (1999) report that the level of firm risk (firm return variance) is an important determinant of the level of remuneration and that this is robust across other measures of firm risk. Failure to allow for firm risk will under-estimate the true pay-performance relationship. Garen (1994) showed that firms with higher levels of risk (as measured by betas from a regression of firms' return on the market return) paid their executives more in salary and less in incentive payments. This is consistent with standard principal-agent theory since risk-averse executives should demand higher base salaries and less performance-related pay when risk is high, in order to avoid bearing the firm's idiosyncratic risk. Core and Larcker (1999), Conyon and Murphy (2000), and Garvey and Milbourn (2003) have all incorporated some measure of firm risk into models specifying the determination of executive pay.

The rest of the paper is organised as follows. In section I we briefly summarise our methodology for assessing pay-performance sensitivities. Section II describes our dataset, and Section III provides some descriptive statistics and patterns in UK executive compensation over time. Section IV discusses the results of our payperformance estimates, and we provide some concluding comments in Section V.

\section{Methodology}

Following Murphy (1999) we write the pay-performance relationship in log-form so that the pay performance estimates may be interpreted as elasticities:

$$
(\text { ExecPAY })_{i t}=\gamma_{i}+\alpha_{t}+\beta i(\text { CompPerformance })_{i t}+\lambda_{i}(\text { Controls })_{i t}+\varepsilon_{i t}
$$

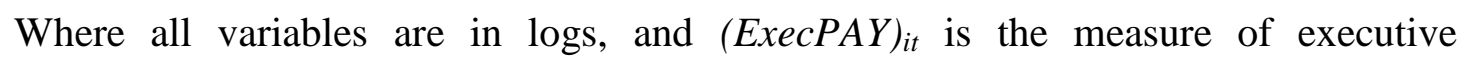
compensation which will be defined as either the annual total board pay or the annual pay of the highest paid director of firm $i$ in year $t ; \gamma_{i}$ refers to an executive/firm 
specific effect for the executive(s) working in firm $i$ that varies across all executives/firms but is constant across time and $\alpha_{t}$ is a time trend. Alternative measures of company performance incorporate shareholders' return, earnings per share, and sales revenues. Control variables include firm size, firm risk, time dummies, number of directors and the number of non-executive directors, as a corporate governance proxy.

Since the sample is a cross section of firms of varying sizes and from different industries there are likely to be time invariant unobserved differences between firms, which may explain some of the variation in pay. Examples of unobserved time invariant effects include director quality, and complexity of the firm. In order to allow for this unobserved heterogeneity, the model will be estimated using fixed effect regressions A fixed effects regression is preferred to a random effects model since the unobserved effects are likely to be correlated with explanatory variables, such as firm size. Since we cannot distinguish between unobserved effects and time invariant observed variables, the industry dummies can only be included in a random effects model.

\section{Data}

\section{A Sample}

There are two main data sources; Hemscott director trading dataset and Datastream. Our sample consisted of 415 companies that were all constituents of the FTSE 350 stock market index over the period January 1994 to December 2006. This list included all those companies that were constituents of the index at the end of September 2002; plus all companies that had been constituents of the FTSE 350 during the period 1994-2002, but who had since become members of the FT Small Sectors or Fledgling Sectors; plus those companies that were de-listed from the FTSE 350 index for reasons such as bankruptcy or takeovers. We collected data on these companies over the period 1994-2002, and subsequently updated the data to 2006. Our sample of 415 firms included 59 firms in the financial services sector, comprising banks, insurance companies, real estate and speciality finance firms (see Appendix 3).

We excluded investment trust firms, and firms that had less than three years' worth of returns/account data and other firms whose data was unavailable from Datastream. 
Panel A of Appendix 2 provides an explanation of how we constructed the final sample of 415 firms. Panel B in Appendix 2 shows the distribution of firms across fiscal years, where companies are allocated to a fiscal year by the date of their accounting year-end. The first and last years have fewer firms since some firms may not have complete accounting year data if their relevant accounting year started or finished outside the sample period.

\section{B Dependent Variables}

For each company in the dataset, we collected two measures of directors' compensation from Datastream annual company accounts: the total remuneration of the whole board and the pay of the highest paid director. Total board pay includes the total of all base salaries and bonuses, directors fees, emoluments for management services and pension contributions paid to, or on behalf of directors. Following the introduction of FRS3 (June 1993), compensation for loss of office and ex gratia payments are also included. Pay of the highest paid director represents the highest remuneration paid to any director for the period. Although we would typically expect this to be the company's CEO, a note of caution is that this variable might apply to a different director in a particular year, if for some reason a large payment was made to some other director. Common to other studies we take log values of pay.

\section{Accounting Years}

The directors' compensation variables are annual payments relating to the company's accounting year. We aligned the cross-sectional units in the panel on the basis of fiscal years, since UK firms typically have different accounting years, and it is necessary to standardise by year for comparison purposes. The fiscal year runs from early April to late March each year, and we allocated firms to the relevant fiscal year by the date of their accounting year-end. A company with an accounting year-end in February 1995 would be allocated to the 1994/95 fiscal year, but a company with a year-end in May 1995 would be allocated to the 1995/96 fiscal year.

One problem with assigning firms to fiscal years was that some firms changed their accounting year-ends during the sample period. There are two types of firms that changed their accounting years: a) those that deferred their accounting year to a later date in the accounting year e.g. September 1999 to December 1999; and b) those that 
brought their accounting year forward to an earlier date e.g. September 1995 to June 1995. In both cases we annualised the reported data where the data related to an accounting period different from 12 months.

\section{Explanatory variables}

It has previously been shown that firm size is the most important determinant in the level of executive compensation, and we used total firm assets as a proxy for firm size in the regressions. Previous work has typically used total sales as the measure for firm size, but for the banking sector this variable understates the size of the firm, and therefore we use total assets. Market capitalisation is an alternative measure of firm size, but is likely to be correlated with total shareholder return. ${ }^{3}$

The most important measure of company performance is the total shareholder return, since the purpose of performance-related pay is to align the interests of the directors with those of the shareholders. We also examined the effect of alternative accounting measures of performance, including earnings per share, return on assets and growth in sales. Although previous UK research has found little evidence of relative performance evaluation, we also included market and industry adjusted returns.

We computed total shareholder return as an annual value by accounting year, as distinct from calendar year, in order to align the performance variables with the relevant accounting variables. We calculated annual returns for each company by cumulating the standard daily return, defined as the percentage change in close-toclose share price plus the dividend payment on the ex-dividend date. Main et al (1996), and Conyon (1997) calculated annual returns by the log of the change in the return index over the whole year. Instead we follow Barber and Lyon (1997) and compute annual abnormal returns as the buy and hold return (BHAR) minus the buy and hold return on a reference portfolio.

$$
B H A R_{T}=\sum_{i} \prod_{t=+1}^{T}\left(1+R_{i t}\right)-\sum_{i} \coprod_{t=+1}^{T}\left(1+E R_{i t}\right)
$$

\footnotetext{
${ }^{3}$ When market capitalisation was used as a firm-size proxy in the regression model, the sign on the return variable was negative. The coefficients on both firm-size proxy variables were quite similar with market capitalisation having a slightly smaller value.
} 
The BHAR approach cumulates daily returns on an annual basis to give total shareholder return for the relevant accounting year. Market and industry adjusted returns are calculated as the actual return minus the expected return. Expected returns are estimated using a CAPM model, which runs a regression of the firm's daily return on that of the daily market return:

$$
R_{i t}=\alpha_{i}+\beta_{i} \operatorname{RFTAll}_{t}+\varepsilon_{i t}
$$

The parameters from this regression $\left(\hat{\alpha}_{i}, \hat{\beta}_{i}\right)$ can be used to calculate expected returns $E\left(R_{i t}\right)=\hat{\alpha}_{i}+\hat{\beta}_{i}$ RFTAll $l_{t}$ where RFTAll is the actual daily return on the FT All Share market index. To obtain the parameter estimates we ran regressions on the daily returns for the year prior to the accounting year. This results in approximately 255 observations in each regression. For the first accounting year, we used in-sample estimates of the coefficients. In the case where firms had changed their accounting years, we estimated the parameters over the full year prior to the new accounting year. The same method is used to obtain expected returns for the industry adjusted returns except regressions are run using the return on the industry index to which the firm belongs. Industry groups are defined in Appendix 3.

Core and Larcker (1999) suggests that different corporate governance arrangements in firms may influence how much they pay their executives. Fernandes et al (2010) report that CEO pay is positively related to institutional ownership, board size, and fraction of independent directors. We include two measures of board structure: the total number of directors, and the proportion of the non-executives on the board as a measure of independence. Firms that have more directors (particularly more executive directors) may pay their whole board more simply because they have more directors to pay. A firm may increase total board pay in one year because there are additions to the board rather than any pay increases to the existing members, and we need to control for this effect. A larger board size may also suggest the firm is more complex, and hence the need for more (higher quality) directors, who will demand more pay. 
Non-executive directors only receive fees for their services, and are paid considerably less than the executive directors on the board. If there were a greater proportion of non-executives one would expect the total board pay to be less (given board size is kept constant). In addition more non-executives may result in the executive directors being paid less due to greater monitoring. Greenbury (1995) recommended that remuneration committees should comprise solely of non-executive directors. An increase in the proportion of non-executives may reflect this fact and therefore since the non-executives are setting the level of executive pay, pay may be lower.

It is difficult to predict the effect board size and composition would have on the pay of the highest paid director. If there are more directors on the board then the highest paid director may have more responsibility in running a larger and possibly more complex board/firm. On the other hand there may be more executives to take on the major roles so that the highest paid director has less responsibility and therefore require lower remuneration since all executives in the firm receive similar pay. Cadbury (1992) recommended that roles should be distributed among executives so no one individual has all the power. Again, a higher proportion of non-executive directors may imply greater monitoring so the executive directors' pay is set at a lower rate. Alternatively if there are few other executive directors, the highest paid director may have more roles and responsibility and actually require higher remuneration.

We include a series of time dummies to allow for macroeconomic shocks, and a variable for each industry group was created. Conyon and Murphy (2000) used only four categories of industry group: mining and manufacturers, utilities, financial services and other. In the Hemscott dataset industry groups are defined by the ten FTSE Actuaries industry sectors listed in Appendix 3. As can be seen from Appendix 3 , most firms in the sample are in the cyclical service group, which makes up almost a third of all observations. The least populated sector with only six firms is cyclical consumer goods. The financial sector has 59 firms spanning banks, insurance companies, real estate, and speciality finance firms. 
Since the dataset is constituted as a panel over several years, monetary variables will be affected by inflation. All nominal monetary variables were adjusted to 2006 values by using the monthly retail price index RPIX, excluding mortgage payments.

\section{Overview of Directors Remuneration: Descriptive Statistics}

Our sample of 415 firms is an unbalanced panel in that some firms leave the sample before the end and others join midway through. The maximum number of firm-year observations is 4,044 but there may be missing observations for some variables. Panel C in Appendix 2 shows the distribution of the number of observations per firm year. Forty percent of firms (167) are in the sample for the full time-series of 12 years, with only about $10 \%$ of firms having less than 6 years worth of data. There were 14 firms that had a fiscal year missing due to a change in account year-ends. There were 18 firms that had an account year that was greater than 12 months and this data had been annualised by Datastream and their returns in our sample were also adjusted.

Table 1 Panel A gives a summary of the pay variables in real terms. The mean of both the total board pay and that of the highest paid director is much greater than the median, suggesting that both pay variables are right skewed with a few firms having unusually large values. The large standard deviations for both pay variables demonstrates there is a wide spread of pay levels across time and between firms in our sample. Both pay variables are higher in the financial firms than in non-financial firms. Figures 1 and 2 plot the levels of average real total board pay and real pay of the highest paid director across the sample period. These figures show these averages across all industries, and for the financial services sector in particular.

\section{[INSERT TABLE 1 ABOUT HERE]}

Average pay generally rose over the whole period with a slight fall in the 2001/2002 accounting year. ${ }^{2}$ The mean total board real pay has risen by $63 \%$ and there has been a 50\% rise in the median real pay, and the mean-median ratio has increased from 1.28 to 1.39. A gap between the median and the mean is likely to be a natural feature of

\footnotetext{
${ }^{2}$ A similar pattern was found when the pay variables were adjusted for wage growth as opposed to inflation.
} 
directors pay. There is likely to be a base level of pay necessary to induce participation, and high variance and non-negative rewards for performance and managing large firms, creating a long tail of unusually high pay. The fact that the mean is rising faster than the median suggests this tail is getting longer, with pay for those very highly paid individuals or high reward periods rising faster than that for basic salaries (we will return to this point later). Figure 1 also documents the growth in board pay of those firms in the financial services sector. Both the mean and median pay in the financial services sectors are higher than for all sectors, but there appears to more time-series volatility in the mean total board pay in the financial services sector, and some evidence that this pay appears to lead board pay in other sectors.

\section{[INSERT FIGURE 1 AND FIGURE 2 ABOUT HERE]}

In figure 2, again there is a substantial difference in the mean and median of the real pay of the highest paid director. Over the entire period 1994/95 to 2005/06 mean pay of the highest paid director has risen by $122 \%$ and median pay by $100 \%$ in real terms, with the mean-median ratio increasing from 1.27 to 1.41 . It is evident that this widening of the gap between the mean and the median has occurred primarily since 2000. Over the sample period there has been an increase in the average pay of the highest paid director in every year except in 2001/2002 where the mean pay fell slightly. The average pay of the highest paid director has been growing at a faster rate then that of the total board pay. This is reflected in the increase in the ratio of the highest paid director pay to the pay of the total board. In the 1994/95 fiscal year this ratio averaged $24 \%$ but by $2005 / 06$ it had risen to $33 \%$. As in Figure 1, it appears that the real pay of the highest paid director in the financial services sector is volatile, and appears to lead executives' pay in other sectors.

Not only are executives getting pay rises well above inflation levels but these are much greater than those of the typical employee in their firm. In our sample on average the average director in a firm earns 12 times more than an average employee in that firm and this ratio has been rising over the sample period (in 1994/95 it was around 9 times and by 2005/06 it was 15 times). Whilst over the sample the mean 
board pay has risen by $63 \%$ and the highest paid director by $122 \%$ the average employee costs has only risen by $11.72 \%$ in real terms ${ }^{4}$.

\section{[INSERT EXHIBIT 2 ABOUT HERE]}

Exhibit 2 shows a comparison of pay growth in the mean of the cash compensation for the total board and highest paid director with that of all employees and management pay growth from the Annual Survey of Hours of Earnings (ASHE). ASHE is a representative sample (about $1 \%$ of the working population) of employees in the UK, available from 1997 onwards. Exhibit 2 shows that over the period 1997-2006 executive pay has risen much faster than that of managers and senior officials and more than double that of all employees in the UK. The evidence we are documenting is that executive cash compensation has grown considerably during our sample period and by more than any comparable group.

\section{[INSERT EXHIBIT 3 ABOUT HERE]}

Exhibit 3 shows the distribution of the average real total board pay and the average pay of the highest paid director by ten industry sectors. These sectors are defined in Appendix 3. It can be seen that total board pay is highest in the non-cyclical services sector which includes food and drug retailers, and telecommunications. The financial services sector which includes banks, insurance companies, real estate and financial specialist companies have the second largest total board pay at $£ 3.545$ million, and the highest paid single director at $£ 915,900$.

\section{[INSERT FIGURE 3 ABOUT HERE]}

Figure 3 shows the percentage change in both pay variables along with the percentage change in the FTSE All Share index for the sample fiscal years 1994/95 to 2005/06. The change in both pay variables appears to follow that of the market index with a slight lag. This may reflect that the largest component of cash compensation, salary, is

\footnotetext{
${ }^{4}$ The only measure of employee wages obtainable from Datastream is total employee costs. This includes all wages and salaries, social security costs and pension costs of all employees including the directors. Since we know the pay of the directors this can be removed and an average cost per employee can also be worked out since we know the total number of employees and the total number of directors. The only problem is we cannot separate the social security costs (employers national insurance) from the employment costs so this may inflate the average employees wage slightly.
} 
set at the beginning of the accounting year. Some of the growth in pay over the period may therefore be attributed to the growth in the stock market. This large pay growth over the sample period we have documented may be attributed to the fact that between the 1996 and 1999 fiscal years the stock market grew by 58\%. We will explore these issues in more detail in the regression results in Section IV below.

\section{[INSERT FIGURE 4 ABOUT HERE]}

The trend to having a majority of non-executive directors on the board is illustrated in figure 4 and Table 1 Panel D which shows the average composition of a company's' board. On average there are approximately nine members on the board and this has remained fairly constant throughout the time period. However the composition of the board has changed in a subtle way. In the 1994/95 the majority of the board were executives, but by the 2005/06 non-executive directors were in the majority. In 1995 $44.5 \%$ of a firm's board comprised of non-executive directors but by 2005/06 fiscal year this had risen to over half at $53.6 \%$. The proportion of non-executives on the board seems to be higher in the FTSE 100 companies then the FTSE 250 companies. In the fiscal year of $2005 / 06$ on average $57.1 \%$ of board members were nonexecutives compared to $51.6 \%$ in FTSE 250 companies. The boards of financial firms have more members than non-financial firms (Walker, 2009), although the mix between executive and non-executives is the same for all firms.

These changes in board composition reflect the impact of the corporate governance reports (Cadbury,1992; Greenbury. 1995), which highlighted the importance of, and recommended increases in, the numbers of non-executive board members. Hampel (1998) recommended that the board should comprise at least a third of nonexecutives, and Higgs (2003) recommended that at least half the board should be nonexecutives. From the above evidence it appears this is already the case, particularly in the FTSE 100 companies. Since the average board size has not changed, the evidence in Figure 4 suggests that firms have increased the number of non-executives at the expense of executive directors. This would suggest that the total board pay should have decreased slightly since non-executives are typically paid much less than executive directors. Since total board pay has in fact risen, the increase in executive- 
only pay is likely to have been underestimated since executives must be receiving a larger slice of total board pay..

Table 1 Panel B reports two measures of firm size: market capitalisation, and total firm assets. The average market capitalisation adjusted for inflation is $£ 3,147.98$ million with a median of only $£ 659.75$ million. The mean total assets are $£ 9,201$ million with a median of $£ 816$ million. Both measures are highly skewed with a few firms being very large. The average market capitalisation and average value of total assets of financial firms are much larger than these measures of firm size for nonfinancial firms. Standard deviations of both size variables suggest there is a large dispersion in firm size within our sample. This removes any worries of there being a firm size bias in only using the FTSE 350 firms and suggests that there is plenty of firm size variation.

\section{Regression Results}

A list and description of the variables used in our regressions can be found in Appendix 1. All regressions were performed on both the log of pay of the whole board and that of the highest paid director. First, the firm's raw return is included as the company performance explanatory variable with the inclusion of adjusted return measures later. Following the approach in Murphy (1999) stock market performance variables were entered in the model in the form $\ln (1+$ return $)$, and total assets were included in log form to reduce the effect of outliers in firm size. Therefore our pay performance estimates are interpreted as elasticities, which is common to the majority of prior studies. In all the regressions the control variables of total assets, number of directors and proportion of non-executives are used. Year dummies are included to allow for any aggregate effects that are not constant over time such as macroeconomic shocks. Model 1 for both the total board pay in Table 2 and for the highest paid director in Table 3 estimates a pooled regression across firms and time. Industry dummies were included to allow for any possibility of differences across industries, but the only sectors that displayed any significant effects were the Resources, Cyclical Consumer Goods, Utilities and Financial sectors, and the reported regression results only highlight sector dummy variables for these industries. Given the high levels of executive pay in Exhibit 3, surprisingly the coefficients on the financial sector dummies are negative. The interpretation is that financials pay their board $23 \%$ less, 
and their highest paid director $25 \%$ less than other industries, after conditioning on the other variables in the regression. These industry dummies show that the high level of pay in the financial sector can be explained by the other variables in Model 2, and in particular is due to the large size of companies in the financial services sector as measured by the total assets of the firm: large firms pay high levels of remuneration to their executives. In fact these results suggest that executives in the financial services sector are underpaid relative to the size of their firm's assets.

[INSERT TABLE 2 and TABLE 3 ABOUT HERE]

\section{A Fixed effects regressions}

Model 2 reports the fixed effects estimates for the total board pay shown in Table 2 and those for the highest paid director in Table 3. An F-test on the significance of the fixed effects that all $\gamma_{i}=0$ is easily rejected for both dependent variables. We also compare the fixed effects regression model with a random effects model and for both sets of regressions a Hausman ${ }^{4}$ test rejects consistent random effects i.e. the unobserved effects are correlated with the explanatory variables so the random effect results will be biased Therefore in interpreting the main regression analysis for both dependent variables we will draw on the fixed effects models.

Firm size has a much larger effect on pay than firm return. In the fixed effects model the total assets' elasticity is around 0.22 for both pay variables implying that a $10 \%$ increase in total assets will lead to a $2 \%$ increase in pay: so larger firms pay their boards/top director considerably more. In contrast, shareholder return has a much smaller effect on executive pay. The shareholder return elasticity is slightly stronger for the pay of the highest paid director. The coefficients in Model 2 of Tables 2 and 3 , suggest that a $10 \%$ increase in shareholder return will lead to a $0.38 \%$ increase in total board pay and a $0.68 \%$ increase in the pay of the highest paid director. A $10 \%$ increase in total assets and total shareholder return translates into a $£ 41,866$ and $£ 7.027$ increase in total board pay respectively at the median level of total board pay of $£ 1,864,005$. In the case of the pay of the highest paid director a $10 \%$ increase in total assets and total shareholder return translates into a $£ 11.815$ and a $£ 3,726$ increase in highest paid director pay at the median level of $£ 543,200$. Clearly executive pay is

\footnotetext{
${ }^{4}$ The test statistic is 27.96 and 23.21 for the Total Board Pay and Highest Paid Director regressions.
} 
more sensitive to firm size than firm performance. The shareholder return estimates for the highest paid director are comparable to Conyon (1997) and Benito and Conyon (1999), but lower than Conyon and Murphy (2000). Our estimates for total board pay are lower than Main et al (1996), who produced estimates of around of 0.15 but this may reflect that their study only used a cross section of 60 large FTSE 100 firms.

The coefficients for the time dummies in the basic fixed effects regression, although not reported in Tables 2 and 3, are shown in Exhibit 4. All of the year dummy variables are positive and mostly significant relative to the 1994/95 fiscal year and the effect seems to get larger as time progresses. This implies that base executive pay, unrelated to company performance or firm size, has been rising through time at well above inflation or employee earnings, as illustrated in Figures 1 and 2.

\section{[INSERT EXHIBIT 4 ABOUT HERE]}

The time variables will be picking up any factors that change over time but are the same across all firms. Even after allowing for firm size and firm performance the growth in average total board pay has grown by $63 \%$ and that of the highest paid director has grown by $122 \%$. This highlights that much of the growth in directors' pay cannot be attributed to the individual firms' performance, and suggests that corporate governance reports that have emphasised aligning executive pay with performance, have been ineffective.

In Model 3 to focus on the pay-performance relationship in the financial services sector we interacted a financial sector dummy with the performance measure, $\ln (1+$ firm return $)$ to see whether pay-performance sensitivity differed between the finance sector and all other industries. We anticipated finding that pay-performance would be more sensitive in the financial sector than other industries. However in the financial services sector, for the two measures of executive pay, although payperformance elasticities are higher than in the remaining industries, these differences are not statistically significant. In unreported results we also investigated the payperformance sensitivity across the other sectors, and identified substantial variation across sectors. In the case of the real pay of the highest paid director, pay- 
performance is significantly higher at the 1 per cent level for the Cyclical Consumer Goods sector.

As might be expected the number of directors on the board, also reflecting firm size, has a positive effect on the total board pay since there are more (and possibly higher quality) directors to pay. From the coefficients in Model 2 of Table 2, an increase in the board size by one director will increase total board pay by $5.8 \%$. From Table 3 , the number of directors has a positive but insignificant effect on the pay of the highest paid director.

The proportion of non-executive directors has opposite effects on the total board pay and the highest paid director pay, though for the latter it is insignificant for the fixed effects models. As the proportion of non-executive directors increases the total pay of the board goes down. From Table 2 a 1\% increase in the proportion of nonexecutives will reduce total board pay by $0.58 \%$. This may be simply because nonexecutives are paid less since they only receive directors' fees so if there are a higher number of non-executives then overall pay will be less (holding board size constant). On the other hand, the proportion of non-executives may be a proxy for the level of monitoring exerted by the board, so more monitoring (more non-executives) will lower total board pay. If this was the case, we might expect the proportion of nonexecutives to have a negative effect on the pay of the highest paid director. In Table 3 , the effect is positive although insignificant. These results suggest that the size of the board and the composition of the board do not affect the level of pay for the highest paid director but do affect the pay of the whole board.

We now turn to the effect of firm risk on the pay-performance relationship. Aggarwal and Samwick (1999) and Garvey and Milbourn (2003) found that riskier firms tend to have lower pay-performance relationships and a smaller proportion of their pay as incentive based pay. Since we have only data on cash compensation we can't directly test the latter but we can look at the former. The firm return was interacted with the cumulative density function of the firm's variance of returns, as our measure of firm risk. For each firm, the variance of daily returns for the previous account year was computed, except in the case of the first year where that years data was used. These variances were then normalised using a cumulative density function (CDF). This 
enabled each firm to have a value between 0 and 1 so the firm with the most risk would have a CDF equal to 1 .

The coefficients on firm return and firm return interacted with the CDF are shown in Model 4, of Tables 2 and 3. The CDF of firm risk is negative but insignificant in the fixed effects regression for both dependent variables, implying that the level of firm risk having no significant effect on the level of cash compensation. When we include the interactive total shareholder return variable with $\mathrm{CDF}$ of firm risk the pay performance relationship changes slightly. ${ }^{5}$ The coefficient on the $\ln (1+$ return $)$ is the pay performance relationship for a firm with no risk. If we know where the firm lies in the return distribution then we can work out their pay performance relationship using the sum of the two coefficients. From the coefficients in the raw return fixed effects regression model a firm with no risk $(\mathrm{CDF}=0)$, has a pay performance estimate of 0.1184 , so that a $10 \%$ increase in total shareholder return will lead to a $1.18 \%$ increase in total board cash compensation. The coefficient on the interactive variable is -0.0956 , so for a firm with the highest level of risk $(\mathrm{CDF}=1)$ their pay performance estimate would be $0.1184-0.0956=0.0228$. For a firm with the median level of risk $(\mathrm{CDF}=0.5)$ their pay performance elasticity would be $0.1184-\left(0.5^{*} 0.0956\right)=0.0706$. This demonstrates that firms with a higher level of risk tend to have lower pay performance relationships, as has been found previously.

A potential endogeneity problem is that pay induces effort and increased effort produces better performance, leading to overstated performance-pay coefficients. To correct for this endogeneity we also estimate the model using GMM. In Model 6 the performance coefficient of the board pay regression remains similar at 0.0374 , but the effect of total assets is reduced from 0.2246 to 0.1234 , but this may reflect that lagged total board pay is included in the regression and total assets in the other regressions will be picking up the persistence of pay. As would be expected the GMM regression shows that there is some persistence in pay. The GMM regression coefficient in Model 6 on firm return is very similar to that from the fixed effects regression. In both Tables 2 and 3 the Hansen test rejects the null of invalid instruments for the GMM models.

\footnotetext{
${ }^{5}$ Including an interaction of firm risk and performance has a high correlation with the performance variable of 0.94 , but the other coefficients are stable with respect to the inclusion of this variable
} 


\section{B Alternative measures of returns ${ }^{6}$}

We have seen that the raw firm return does have an effect on directors' pay. But firms may be showing notable performance because the whole market/industry is performing well. Therefore Model 5 in Tables 2 and 3 reports the use of market adjusted returns, in which a CAPM estimate of expected returns is deducted from the raw return. If the market/industry is rising, do firms take this into account before setting pay levels? Is executive compensation related to the out-performance of the firm relative to the market or industry? For both pay variables it seems that market adjusted returns makes very little difference to the significance, sign and size of the return coefficients. In unreported results we found that industry adjusted return has a slightly larger effect but only makes a marginal difference. In comparison with the earlier reported numbers, a 10\% increase in total return above the market return from Model 5 increases total board pay by $£ 6,766$. Using similar information from Table 3 , if return is greater then the market by $10 \%$, the median highest paid director pay will increase by $£ 3,634$. These estimates would suggest that firms do not make use of relative performance evaluation.

\section{Heterogeneous results}

Our fixed effects estimates in Tables 2 and 3 are an average across time and companies. Any estimated pay-performance relationship will only be an average, but the pay-performance relationship may vary across firms, time or industries or other factors. By including a set of interactive variables we may allow for the payperformance relationship to vary across those variables. The inclusion of the firm return variable interacted with the year dummy variables allows us to see if the payperformance relationship has changed over time for both pay variables. The raw return firm variable was interacted with the year dummies in the regression along with the usual control variables and a full set of year dummies.

\section{[INSERT FIGURE 5 ABOUT HERE]}

\footnotetext{
${ }^{6} \mathrm{We}$ also used different measures of performance, namely accounting based methods such a s change in real sales, return on assets, real net EPS; but all these variables were insignificant
} 
Figure 5 shows how the pay-performance relationship has changed over the sample period plotting the estimates of the coefficients on the interactive dummy variables. Following proposals from a series of corporate governance reports suggesting stronger links between pay and performance, one might have expected that the payperformance relationship would have increased over the period. Over the whole sample it is possible to discern a slight rising trend in the pay-performance elasticities for both pay variables, although the time series movement is volatile. For the total board it has risen from 0.02 in 1995 to 0.106 in 2006 and for the highest paid director it has risen from 0.034 to 0.288 . There appears to be a pattern that elasticities are increasing when the stock market is rising, but a weaker relationship between pay and performance when stock prices are falling. F-tests on the differences in these payperformance elasticities were $\mathrm{F}(11,3205)=0.78$, and $\mathrm{F}(11,3201)=1.10$ for total pay and highest paid director respectively, and hence we cannot reject the null hypothesis that all of these coefficients are equal.

\section{[INSERT FIGURE 6 ABOUT HERE]}

We may also examine how the pay size relationship has changed over time. Interactive dummy variables of sales and year dummies were included in the regression. Figure 6 shows the pay size elasticities over the sample period. The pay size relationship has fluctuated around a mean of about 0.22 for both pay variables. In the 1994/95 fiscal year the pay size elasticity was 0.228 and 0.208 for total pay and that of the highest paid director respectively. By 2005/06 they had risen to 0.234 and 0.241 respectively. F-tests for the equality of the pay-size elasticities coefficients are $\mathrm{F}(11,3205)=1.54$ for the total board pay and $\mathrm{F}(11,3201)=1.21$ for the pay of the highest paid director. This evidence suggests that there is no significant trend over time for the pay-size sensitivity for either pay measure. Murphy (1999) reports that the pay size relationship had fallen for executive compensation in the US.

\section{[INSERT TABLE 4 ABOUT HERE]}

We also examined how the pay-performance relationship varied across different categories. For variables that varied across time, interactive variables were included in the basic fixed effect regressions, and Table 4 shows the effect of these interactive 
time dummies. If directors are rewarded through a combination of base pay which is unrelated to performance plus performance related bonuses which can only be positive then you will naturally see pay being sensitive to exceptionally good performance but not exceptionally bad performance. This pattern will lead to pooled estimates we have estimated above to somewhat mask the full extent of rewards to exceptionally good performance. On the other hand such one-sided risks can lead to high risk taking as poor performance is not punished to the same degree as good performance is rewarded. There was some suggestion of this in figure 3. This was tested by interacting the firm return variable with whether firms were below or above the median return of the sample firms in each fiscal year. For both pay variables there does seem to be a difference between firms below and above median firm return. The pay-performance relationship is significant for firms above median return but insignificant for those below. For firms above the median return the average payperformance relationship is 0.0465 for the total board pay and 0.0968 for the highest paid director. These estimates are higher then the average pay-performance relationships found in the original fixed effect regressions. Although not reported results were similar when the return was interacted with whether firms are above or below the return on the FTSE All Share index in the given fiscal year. We also differentiated between the financial services sector and all other sectors, and it appears that this difference between pay-performance elasticities for above the median and below the median firms are more pronounced for firms in the financial services sector. However an F-test on the equality of these coefficients could not be rejected.

Next, the firm return was interacted with whether the fiscal year was during the bull market up to March 2000, the subsequent bear market up to 2003, and the bull market since 2004. The pay-performance relationship was stronger for both pay variables during the bear market fall. This suggests that firms were receiving pay based on the performance of the whole market when the market was booming, and then based on their own performance after the stock market crashed. An alternative explanation would be that firms are under more pressure to comply with the corporate governance reports when the stock market is in decline.

The third set of interactive variables look at the size of firms, split into whether the firms were above or below median total assets in the particular fiscal year. There 
appears to be a stronger pay-performance relationship for larger firms than smaller firms. However this is not the case for firms in the financial services sector, where the pay-performance relationship for total board pay is stronger for firms below median assets.

\section{Conclusions}

The objective of this paper has been to examine the determinants of executive pay, how this relationship has changed over time, and whether there is any evidence that executive remuneration packages in the financial services sector might have contributed to the global financial crisis of 2007/08. We argued that if remuneration structures in financial firms were responsible for the crisis, then the pay-performance relationship between executive pay and short-term profits should have been greater than in other sectors. Our pay measures comprised salary and non-equity bonuses. According to Fernandes et al (2010) these components typically constitute around seventy per cent of UK executives' pay packages. Still, a caveat to our results is that our pay variables did not include equity incentive payments. , Following the financial crisis, regulators have been searching to identify an appropriate regulatory structure to monitor non-equity incentives as a component of executive pay. For example, Recommendation 33 of the Walker Report (2009a) proposes that half of the value of incentive payments to executives should only be vested after between three and five years.

Our main findings are that firm size has a dominant influence on the level of executive compensation. Surprisingly we found that although total board pay and the pay of the highest paid director was relatively high in the financial sector, there was no significant difference in the pay-performance sensitivities between the financial sector and other industries. Further, although the pay-performance point estimates are slightly larger in the finance sector, the values are so small as to make it unlikely that executives in the finance sector were over-incentivised. The primary factor related to executive pay appears to be firm size. It has been argued that remuneration packages in the financial services sector may have been partly responsible for the global financial crisis. It would appear that the mechanism for such an impact is not through the relationship between executive pay and stock market performance, but instead through the incentive for executives to ensure that their firm's assets are as large as 
possible. Of course it could be argued that the experience of the financial crisis has shown that banks in particular are so important to the functioning of the global economy, that compensation packages should be less sensitive to performance than for non-financial firms.

Following the adoption of a series of corporate governance reforms throughout the 'nineties we expected to find an increase in these pay-performance elasticities over time, since a common theme in these reforms was that executive pay should be related to company performance. However we found little evidence of any upward trend in pay-performance sensitivities, but we did identify an asymmetric relationship, in that pay-performance elasticities were high when stock returns were high, but that pay was less sensitive to performance when stock returns were low. This follows if executives are paid a base salary unrelated to performance, plus bonuses, which are related to above average performance and can only be positive. This one sided risk model creates an asymmetry in the pay-performance link which might potentially encourage excessive risk taking by executives in all sectors. Our results suggest that there is a stronger relationship between executive cash pay and company performance for exceptional out-performance but not unusual under-performance. A final limitation to these findings, is that there may be other penalties for underperformance that we have not considered, such as turnover and loss of reputation in the managerial labour market (Renneboog and Trojanowski, 2010). 
Table 1: Descriptive statistics

This table reports summary statistics (mean, median and standard deviation) of the variables used in our analysis. The data is provided for all firms, and the split between financial firms and all nonfinancial firms. Panel A reports the two definitions of executive compensation: total board pay and pay of the highest paid director in $£ 000$ s per accounting year; Panel B reports two measure of firm size: market capitalization and total assets, both in $£$ million; Panel $\mathrm{C}$ reports measures of firm performance, including the buy-and-hold raw return, net earnings per share, and the return on assets; Panel D reports a number of corporate governance measures, including the total number of directors on the board, and the split between the number of executive and non-executive directors. For further definitions of all variables see Appendix 1. All monetary variables are adjusted to 2005/06 fiscal year prices

\begin{tabular}{|c|c|c|c|c|}
\hline & No. Obs. & Mean & Std Dev & Median \\
\hline \multicolumn{5}{|l|}{ Panel A: Pay Variables } \\
\hline Real Total Board Pay $\left(£^{\prime} 000\right)$ : & 3,271 & $2,528.9$ & $2,188.8$ & $1,864.0$ \\
\hline Financial firms & 546 & $3,544.8$ & $3,016.4$ & $2,407.9$ \\
\hline All non-financial firms & 3,175 & $2,354.2$ & $1,960.8$ & $1,773.4$ \\
\hline Real Highest Paid Director $\left(£^{\prime} 000\right)$ : & 3,715 & 733.79 & 721.08 & 543.20 \\
\hline Financial firms & 544 & 915.9 & 903.5 & 618.9 \\
\hline All non-financial firms & 3,171 & 702.6 & 680.2 & 526.0 \\
\hline \multicolumn{5}{|l|}{ Panel B: Firm Size Variables } \\
\hline Real Market Capitalisation (£m): & 2,859 & $3,147.98$ & $9,892.8$ & 659.75 \\
\hline Financial firms & 415 & $4,964.72$ & $10,732.8$ & 992.84 \\
\hline All non-financial firms & 2,444 & $2,839.49$ & $9,711.6$ & 623.38 \\
\hline Real Total Sales $(£ m)$ & 2,826 & $2,318.28$ & $5,638.0$ & 634.1 \\
\hline Financial firms & 405 & $3,484.32$ & $6,598.4$ & 362.4 \\
\hline All non-financial firms & 2,421 & $2,123.22$ & $5,438.1$ & 693.8 \\
\hline Real Total Assets $(£ m)$ & 3,690 & $9,201.20$ & $44,400.0$ & 816.4 \\
\hline Financial firms & 534 & $46,000.00$ & $102,000.0$ & $2,528.6$ \\
\hline All non-financial firms & 3,156 & $2,981.45$ & $17,200.0$ & 700.8 \\
\hline \multicolumn{5}{|l|}{ Panel C: Performance Variables } \\
\hline Firm Return (\%): & 3,703 & 16.94 & 71.10 & 9.27 \\
\hline Financial firms & 544 & 15.62 & 46.37 & 11.67 \\
\hline All non-financial firms & 3,159 & 17.17 & 74.54 & 8.54 \\
\hline Real Net EPS (pence): & 3,688 & 16.3 & 155.8 & 17.2 \\
\hline Financial firms & 533 & 25.9 & 71.1 & 24.7 \\
\hline All non-financial firms & 3,155 & 14.7 & 165.8 & 16.1 \\
\hline Real Return on Assets $(\%)$ : & 3,690 & 6.13 & 18.77 & 7.08 \\
\hline Financial firms & 534 & 2.77 & 9.92 & 2.13 \\
\hline All non-financial firms & 3,156 & 7.00 & 19.82 & 8.05 \\
\hline \multicolumn{5}{|l|}{ Panel D: Board Structure Variables } \\
\hline No. of Directors: & 3,719 & 9.5 & 2.9 & 9 \\
\hline Financial firms & 547 & 11.4 & 3.7 & 11 \\
\hline All non-financial firms & 3,172 & 9.2 & 2.6 & 9 \\
\hline No. of Executive Directors: & 3,702 & 4.6 & 1.9 & 4 \\
\hline Financial firms & 543 & 5.4 & 2.1 & 5 \\
\hline All non-financial firms & 3,158 & 4.5 & 1.8 & 4 \\
\hline No. of Non-executive Directors: & 3,702 & 4.9 & 2.1 & 4 \\
\hline Proportion of Non-executives (\%): & 3,702 & 0.51 & 0.14 & 0.5 \\
\hline
\end{tabular}


Table 2: Total Board Pay Regressions

Table shows results of the pay-performance regression in equation (1) where the dependent variable is $\ln ($ Total Board Pay). Explanatory variables include: the $\ln$ (Total Assets) measured in Emillions; ln (1+firm return), with firm raw return calculated as buy-and-hold returns in equation (2); market adjusted return includes a CAPM adjustment to the buy-and-hold returns in equation (3); $\%$ of non-executives is fraction of board who are non-executive directors; No of Directors is total number of executive and non-executive directors on Board; and CDF Firm Risk is measure of riskiness of firm. All monetary variables are inflated to 2006 prices using the RPIX. Standard errors (in brackets) calculated using the Huber-White-Sandwich estimator which adjusts for correlation within a firm; * denotes significant at 5\%; ** denotes significant at $1 \%$; Time dummies are included but not reported; Industry dummies for 9 sectors are included but only reported when relevant; reference sector is Cyclical Services.

\begin{tabular}{|c|c|c|c|c|c|c|}
\hline & $\begin{array}{r}\text { OLS } \\
\text { Pooled } \\
(1)\end{array}$ & Fixed Effects (2) & $\begin{array}{r}\text { FE with financials } \\
\text { interaction and firm } \\
\text { return (3) }\end{array}$ & $\begin{array}{r}\text { FE with Firm Risk } \\
\text { (4) }\end{array}$ & $\begin{array}{r}\text { FE with CAPM- } \\
\text { returns } \\
(5)\end{array}$ & $\begin{array}{r}\text { GMM } \\
(6)\end{array}$ \\
\hline \multirow[t]{2}{*}{$\ln$ (Total Assets) } & 0.2206 & 0.2246 & 0.2245 & 0.223 & 0.2237 & 0.1234 \\
\hline & {$[0.007]^{* *}$} & {$[0.026]^{* *}$} & {$[0.026] * *$} & {$[0.022]^{* *}$} & {$[0.026]^{* *}$} & {$[0.016]^{* *}$} \\
\hline \multirow[t]{2}{*}{$\ln (1+$ firm return $)$} & 0.0243 & 0.0377 & 0.0329 & 0.1184 & 0.0363 & 0.0374 \\
\hline & {$[0.033]$} & {$[0.013]^{* *}$} & {$[0.014]^{*}$} & {$[0.038]^{* *}$} & {$[0.013]^{* *}$} & {$[0.014] * *$} \\
\hline \multirow[t]{2}{*}{$\%$ of non-executives } & -0.8979 & -0.5839 & -0.5889 & -0.5034 & -0.5779 & -0.6563 \\
\hline & {$[0.060]^{* *}$} & {$[0.094]^{* *}$} & {$[0.094]^{* *}$} & {$[0.101]^{* *}$} & {$[0.093]^{* *}$} & {$[0.087]^{* *}$} \\
\hline \multirow[t]{2}{*}{ No of Directors } & 0.0862 & 0.0585 & 0.0585 & 0.0597 & 0.059 & 0.0591 \\
\hline & {$[0.004]^{* *}$} & {$[0.006]^{* *}$} & {$[0.006]^{* *}$} & {$[0.006]^{* *}$} & {$[0.006]^{* *}$} & {$[0.008] * *$} \\
\hline \multirow[t]{2}{*}{ lag total board pay } & & & & & & 0.3357 \\
\hline & & & & & & {$[0.055]^{* *}$} \\
\hline \multirow[t]{2}{*}{ CDF Firm Risk } & & & & -0.0131 & & \\
\hline & & & & {$[0.032]$} & & \\
\hline \multirow{2}{*}{$\begin{array}{l}\text { CDF Firm Risk* } \\
\ln (1+\text { firm return })\end{array}$} & & & & -0.0956 & & \\
\hline & & & & {$[0.048]^{*}$} & & \\
\hline \multicolumn{7}{|l|}{ Industry dummies: } \\
\hline \multirow[t]{2}{*}{ Resources } & -0.1252 & & & & & \\
\hline & {$[0.038]^{* *}$} & & & & & \\
\hline \multirow[t]{2}{*}{ Cyclical Consumer } & 0.212 & & & & & \\
\hline & {$[0.052]^{* *}$} & & & & & \\
\hline \multirow[t]{2}{*}{ Utilities } & -0.4592 & & & & & \\
\hline & {$[0.032]^{* *}$} & & & & & \\
\hline \multirow[t]{2}{*}{ Financials } & -0.2329 & & & & & \\
\hline & {$[0.030]^{* *}$} & & & & & \\
\hline \multirow{2}{*}{$\begin{array}{l}\text { Financials dummy* } \\
\ln (1+\text { firm return })\end{array}$} & & & 0.0632 & & & \\
\hline & & & [0.041] & & & \\
\hline \multirow[t]{2}{*}{ Constant } & 4.0264 & 4.0264 & 4.0358 & 4.0148 & 4.0336 & 3.2868 \\
\hline & {$[0.081]^{* *}$} & {$[0.081]^{* *}$} & {$[0.330]^{* *}$} & {$[0.273]^{* *}$} & {$[0.332]^{* *}$} & {$[0.266]^{* *}$} \\
\hline Observations & 3,643 & 3,643 & 3,639 & 3,074 & 3,636 & 3,221 \\
\hline $\begin{array}{l}\text { Hansen Test Invalid } \\
\text { Insts }\end{array}$ & & & & & & 69.32 \\
\hline F-test $\gamma_{i}=0$ & & $\mathrm{~F}(411,3216)=15.1$ & $F(411,3215)=15.06$ & $F(411,2647)=13.4$ & $F(411,3209)=15.1$ & \\
\hline R-squared & 0.634 & 0.406 & 0.406 & 0.386 & 0.406 & \\
\hline Number of firms & & 412 & 412 & 412 & 412 & 412 \\
\hline
\end{tabular}




\section{Table 3: Highest Paid Director Regressions}

Table shows results of the pay-performance regression in equation (1) where the dependent variable is $\ln ($ Highest Paid Director). Explanatory variables include: the $\ln$ (Total Assets) measured in £millions; ln (1+firm return), with firm raw return calculated as buy-and-hold returns in equation (2); market adjusted return includes a CAPM adjustment to the buy-and-hold returns in equation (3);\% of non-executives is fraction of board who are nonexecutive directors; No of Directors is total number of executive and non-executive directors on Board; and CDF Firm Risk is measure of riskiness of firm. All monetary variables are inflated to 2006 prices using the RPIX. Standard errors (in brackets) calculated using the Huber-White-Sandwich estimator which adjusts for correlation within a firm; * denotes significant at 5\%; ** denotes significant at 1\%; Time dummies are included but not reported; Industry dummies for 9 sectors are included but only reported when relevant; reference sector is Cyclical Services.

\begin{tabular}{|c|c|c|c|c|c|c|}
\hline & $\begin{array}{r}\text { OLS } \\
\text { Pooled (1) }\end{array}$ & Fixed Effects (2) & $\begin{array}{r}\text { FE with } \\
\text { financials } \\
\text { interaction and } \\
\text { firm return }(3)\end{array}$ & $\begin{array}{r}\text { FE with Firm Risk } \\
\text { (4) }\end{array}$ & $\begin{array}{r}\text { FE with CAPM- } \\
\text { returns } \\
(5)\end{array}$ & $\begin{array}{r}\text { GMM } \\
(6)\end{array}$ \\
\hline \multirow[t]{2}{*}{$\ln$ (Total Assets) } & 0.2152 & 0.2175 & 0.2174 & 0.2177 & 0.2162 & 0.1192 \\
\hline & {$[0.008]^{* *}$} & {$[0.025]^{* *}$} & {$[0.024]^{* *}$} & {$[0.022]^{* *}$} & {$[0.024] * *$} & {$[0.021]^{* *}$} \\
\hline \multirow[t]{2}{*}{$\ln (1+$ firm return $)$} & 0.0732 & 0.0686 & 0.0654 & 0.1364 & 0.0669 & 0.0648 \\
\hline & {$[0.036]^{*}$} & {$[0.016]^{* *}$} & {$[0.016]^{* *}$} & {$[0.043]^{* *}$} & {$[0.015]^{* *}$} & {$[0.018]^{* *}$} \\
\hline \multirow[t]{2}{*}{$\%$ of non-executives } & 0.2107 & 0.1212 & 0.1178 & 0.1583 & 0.1329 & 0.3856 \\
\hline & {$[0.071]^{* *}$} & {$[0.106]$} & {$[0.106]$} & {$[0.116]$} & {$[0.104]$} & {$[0.121]^{* *}$} \\
\hline \multirow[t]{2}{*}{ No of Directors } & 0.0222 & -0.0025 & -0.0026 & -0.0022 & -0.0019 & -0.0099 \\
\hline & {$[0.005]^{* *}$} & [0.006] & {$[0.006]$} & {$[0.006]$} & {$[0.006]$} & [0.013] \\
\hline \multirow[t]{2}{*}{ lag total board pay } & & & & & & 0.3574 \\
\hline & & & & & & {$[0.068] * *$} \\
\hline \multirow[t]{2}{*}{ CDF Firm Risk } & & & & -0.0169 & & \\
\hline & & & & {$[0.037]$} & & \\
\hline \multirow{2}{*}{$\begin{array}{l}\text { CDF Firm Risk* } \\
\text { ln }(1+\text { firm return })\end{array}$} & & & & -0.0898 & & \\
\hline & & & & {$[0.057]$} & & \\
\hline \multicolumn{7}{|l|}{ Industry dummies: } \\
\hline \multirow[t]{2}{*}{ Resources } & -0.1753 & & & & & \\
\hline & {$[0.045]^{* *}$} & & & & & \\
\hline \multirow[t]{2}{*}{ Cyclical Consumer } & 0.2354 & & & & & \\
\hline & {$[0.064]^{* *}$} & & & & & \\
\hline \multirow[t]{2}{*}{ Utilities } & -0.6006 & & & & & \\
\hline & {$[0.038]^{* *}$} & & & & & \\
\hline \multirow[t]{2}{*}{ Financials } & -0.2500 & & & & & \\
\hline & {$[0.033]^{* *}$} & & & & & \\
\hline \multirow{3}{*}{$\begin{array}{l}\text { Financials dummy* } \\
\ln (1+\text { firm return })\end{array}$} & & & & & & \\
\hline & & & 0.0424 & & & \\
\hline & & & {$[0.047]$} & & & \\
\hline \multirow[t]{2}{*}{ Constant } & 2.8502 & 3.0228 & 3.0257 & 3.0099 & 3.0247 & 2.1213 \\
\hline & {$[0.090] * *$} & {$[0.305]^{* *}$} & {$[0.304]^{* *}$} & {$[0.269]^{* *}$} & {$[0.305] * *$} & {$[0.341]^{* *}$} \\
\hline Observations & 3,639 & 3,639 & 3,639 & 3,071 & 3,632 & 3,219 \\
\hline $\begin{array}{l}\text { Hansen Test Invalid } \\
\text { Insts }\end{array}$ & & & & & & 65.51 \\
\hline F-test all $\gamma_{\mathrm{i}}=0$ & & $\mathrm{~F}(411,3212)=13.8$ & $\mathrm{~F}(411,3211)=13.8$ & $F(411,2644)=12.6$ & $\mathrm{~F}(411,3205)=13.7$ & \\
\hline R-squared & 0.458 & 0.344 & 0.344 & 0.311 & 0.346 & \\
\hline Number of firms & & 412 & 412 & 412 & 412 & 412 \\
\hline
\end{tabular}




\section{Table 4: Coefficients on interactive return variables, by median}

Table shows the effect of interactive dummy variables that vary across time. Panel A splits estimated pay-performance elasticities across firms with above and below median returns in any fiscal year, and by financial and non-financial sectors; Panel B splits estimated pay-performance elasticities across years 1994-200; 2001-2003; 2004-2006, and by financial and non-financial sectors; Panel C splits estimated pay-performance elasticities across firms with above and below median size in any fiscal year, and by financial and non-financial sectors.

\begin{tabular}{|c|c|c|}
\hline Variable interacted with firm return & $\begin{array}{l}\text { Total Board } \\
\text { Pay }\end{array}$ & $\begin{array}{l}\text { Highest paid } \\
\text { Director }\end{array}$ \\
\hline \multicolumn{3}{|l|}{ Panel A: Firm return } \\
\hline \multirow{2}{*}{$\begin{array}{l}\text { Firms with return above median return in fiscal } \\
\text { year (All sectors excl. Financial) }\end{array}$} & 0.0465 & 0.0968 \\
\hline & {$[0.020]^{*}$} & {$[0.024]^{* *}$} \\
\hline \multirow{2}{*}{$\begin{array}{l}\text { Firms with return below median return in fiscal } \\
\text { year (All sectors excl Financial) }\end{array}$} & 0.0205 & 0.0372 \\
\hline & [0.019] & [0.022] \\
\hline Equality of coeffs & $F(1,2748)=0.69$ & $F(1,2746)=2.53$ \\
\hline \multirow[t]{2}{*}{$\begin{array}{l}\text { Firms with return above median return in fiscal } \\
\text { year (Financial Sector) }\end{array}$} & 0.1594 & 0.1962 \\
\hline & {$[0.068]^{*}$} & {$[0.080]^{*}$} \\
\hline \multirow{3}{*}{$\begin{array}{l}\text { Firms with return below median return in fiscal } \\
\text { year (Financial Sector) }\end{array}$} & & \\
\hline & 0.0891 & 0.0686 \\
\hline & {$[0.075]$} & {$[0.088]$} \\
\hline Equality of coeffs & $\mathrm{F}(1,451)=0.4$ & $\mathrm{~F}(1,449)=0.95$ \\
\hline \multicolumn{3}{|l|}{ Panel B: Stock Market Performance } \\
\hline \multirow{2}{*}{$\begin{array}{l}\text { Bull market performance fiscal year<2001 (All } \\
\text { sectors excl. Financial) }\end{array}$} & 0.0289 & 0.0658 \\
\hline & {$[0.018]$} & {$[0.021] * *$} \\
\hline \multicolumn{3}{|l|}{ Bear market performance fiscal year $>2000 \&$} \\
\hline$<2003$ & 0.0482 & 0.0608 \\
\hline (All sectors excl. Financial) & {$[0.022]^{*}$} & {$[0.026]^{*}$} \\
\hline \multirow{2}{*}{$\begin{array}{l}\text { Bull market performance fiscal year>2003 (All } \\
\text { sectors excl. Financial) }\end{array}$} & 0.0206 & 0.0689 \\
\hline & {$[0.023]$} & {$[0.028]^{*}$} \\
\hline Equality of coeffs & $\mathrm{F}(2,2747)=0.41$ & $\mathrm{~F}(2,2745)=0.02$ \\
\hline \multicolumn{3}{|l|}{ Bull market performance fiscal year $<2001$} \\
\hline (Financial Sector) & {$[0.068]$} & [0.080] \\
\hline \multirow{3}{*}{$\begin{array}{l}\text { Bear market performance fiscal year }>2000 \& \\
<2003 \text { (Financial Sector) }\end{array}$} & & \\
\hline & 0.2258 & 0.208 \\
\hline & {$[0.075]^{* *}$} & {$[0.088]^{*}$} \\
\hline \multirow{3}{*}{$\begin{array}{l}\text { Bull market performance fiscal year }>2003 \\
\text { (Financial Sector) }\end{array}$} & & \\
\hline & -0.0052 & 0.1125 \\
\hline & [0.101] & [0.119] \\
\hline Equality of coeffs & $\mathrm{F}(2.450)=1.81$ & $\mathrm{~F}(2,448)=0.51$ \\
\hline \multicolumn{3}{|l|}{ Panel C: Firm Size } \\
\hline \multirow{2}{*}{$\begin{array}{l}\text { Firms above median assets (All Sectors excl. } \\
\text { Financial) }\end{array}$} & 0.0512 & 0.0988 \\
\hline & {$[0.021]^{*}$} & {$[0.025]^{* *}$} \\
\hline \multirow{2}{*}{$\begin{array}{l}\text { Firms below median assets (All Sectors excl. } \\
\text { Financial) }\end{array}$} & 0.0263 & 0.0535 \\
\hline & {$[0.013]^{*}$} & {$[0.016]^{* *}$} \\
\hline Equality of coeffs & $\mathrm{F}(1,2748)=1.29$ & $\mathrm{~F}(1,2746)=2.51$ \\
\hline \multirow[t]{2}{*}{ Firms above median assets (Financial) } & 0.0947 & 0.0988 \\
\hline & {$[0.063]$} & {$[0.025]^{* *}$} \\
\hline \multirow[t]{2}{*}{ Firms below median assets (Financial) } & 0.1518 & 0.0535 \\
\hline & {$[0.056]^{* *}$} & {$[0.016] * *$} \\
\hline Equality of coeffs & $\mathrm{F}(1,453)=0.53$ & $F(1,451)=1.83$ \\
\hline
\end{tabular}




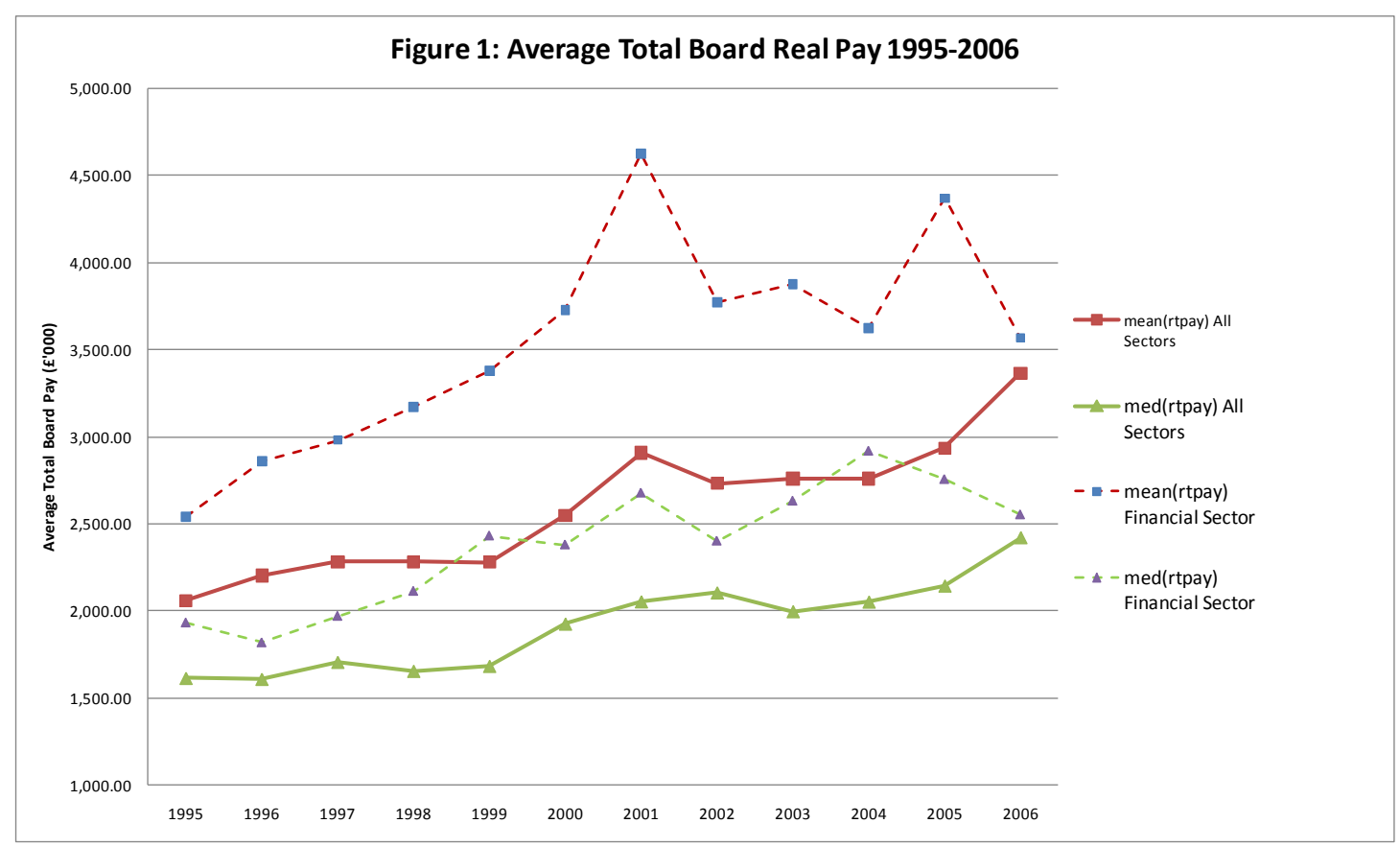

Fig. 1. Average real total board pay 1994/95-2005/06; Pay is cash compensation (salary, bonus and pension contributions) and is adjusted to 2005/06 fiscal year prices.

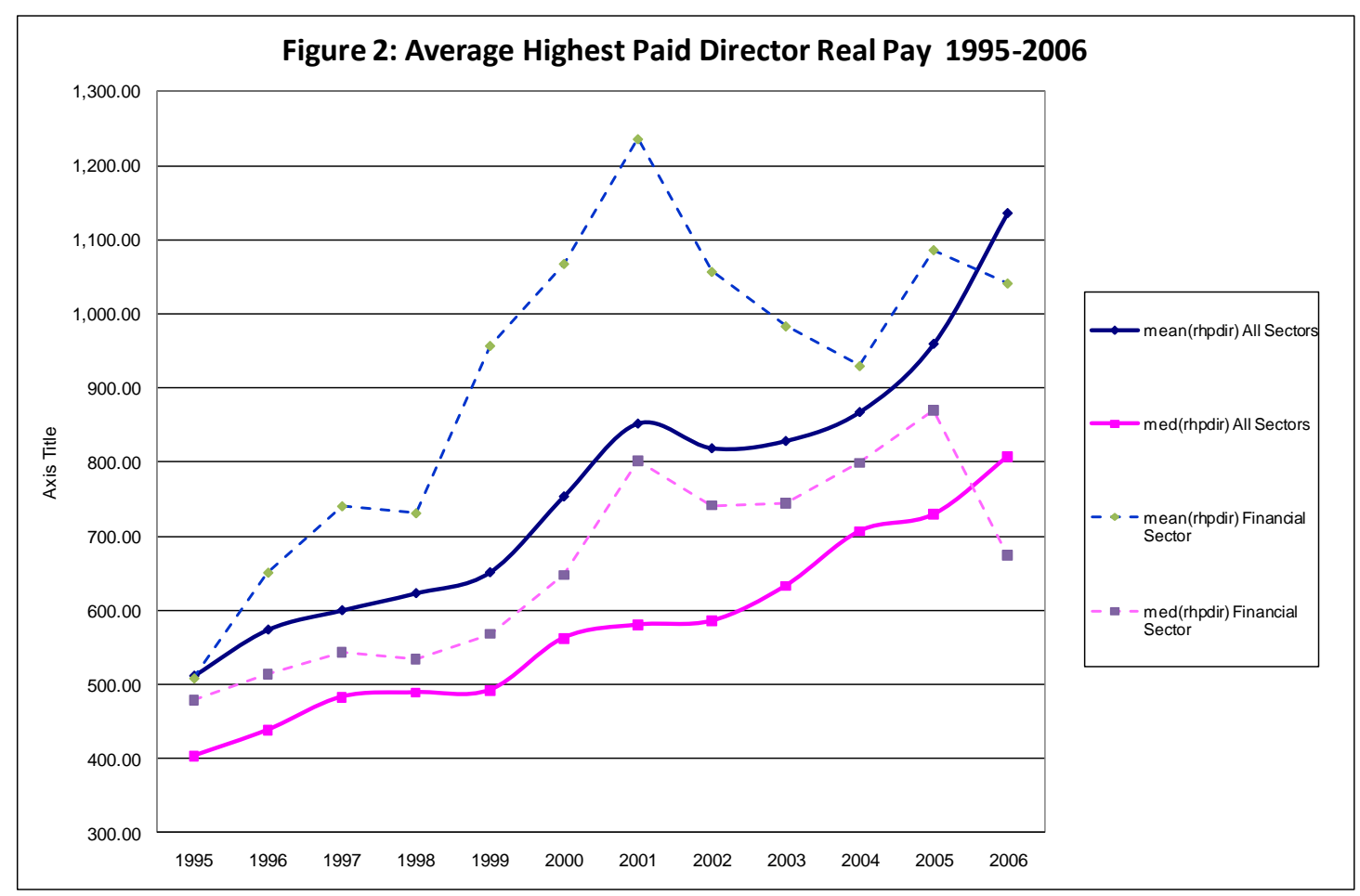

Fig. 2. Average real pay of highest paid director 1994/95-2005/06; Pay is cash compensation (salary, bonus and pension contributions) and is adjusted to 2005/06 fiscal year prices. 
Exhibit 1: Comparison of the use of Incentive and Non-Incentive pay in the Banking and Non-Banking Sectors between years 2000 and 2006

\begin{tabular}{|c|c|c|c|c|c|c|c|c|}
\hline \multirow[t]{2}{*}{ Company } & \multicolumn{4}{|c|}{ Year 2000} & \multicolumn{4}{|c|}{ Year 2006} \\
\hline & $\begin{array}{l}\text { Total } \\
\text { comp } \\
(£ m \text { in } \\
2000)\end{array}$ & $\begin{array}{l}\text { All } \\
\text { non- } \\
\text { Incent } \\
\text { pay/TC }\end{array}$ & $\begin{array}{l}\text { Non- } \\
\text { equity } \\
\text { Incent } \\
\text { pay/TC }\end{array}$ & $\begin{array}{l}\text { Equity } \\
\text { Incent } \\
\text { pay/TC }\end{array}$ & $\begin{array}{l}\text { Total } \\
\text { comp } \\
(£ m \text { in } \\
2006)\end{array}$ & $\begin{array}{l}\text { All } \\
\text { non- } \\
\text { Incent } \\
\text { pay/TC }\end{array}$ & $\begin{array}{l}\text { Non- } \\
\text { equity } \\
\text { Incent } \\
\text { pay/TC }\end{array}$ & $\begin{array}{l}\text { Equity } \\
\text { Incent } \\
\text { pay/TC }\end{array}$ \\
\hline \multicolumn{9}{|c|}{ Panel A: Total Board Pay, Banks } \\
\hline Barclays & 12,827 & $26.3 \%$ & $9.8 \%$ & $63.8 \%$ & 44,380 & $13.3 \%$ & $38.2 \%$ & $48.5 \%$ \\
\hline HSBC & 10,489 & $50.8 \%$ & $24.2 \%$ & $24.9 \%$ & 15,136 & $38.6 \%$ & $23.6 \%$ & $37.9 \%$ \\
\hline Lloyds & 9,119 & $43.7 \%$ & $14.4 \%$ & $41.9 \%$ & 26,787 & $21.5 \%$ & $19.8 \%$ & $58.7 \%$ \\
\hline RBS & 14,716 & $28.9 \%$ & $23.6 \%$ & $47.4 \%$ & 30,391 & $32.2 \%$ & $34.0 \%$ & $33.8 \%$ \\
\hline Average & & $37.4 \%$ & $18.0 \%$ & $44.5 \%$ & & $26.4 \%$ & $28.9 \%$ & $44.7 \%$ \\
\hline \multicolumn{9}{|c|}{ Panel B: Total Board Pay, non-Banks } \\
\hline Glaxo & 16,723 & $24.0 \%$ & $13.0 \%$ & $62.9 \%$ & 20,341 & $12.8 \%$ & $11.1 \%$ & $76.1 \%$ \\
\hline Hanson & 4,201 & $53.2 \%$ & $10.4 \%$ & $36.5 \%$ & 4,049 & $41.0 \%$ & $16.6 \%$ & $42.4 \%$ \\
\hline Marks\&Spencers & 14,081 & $21.9 \%$ & $0.4 \%$ & $77.7 \%$ & 8,023 & $27.3 \%$ & $20.5 \%$ & $52.2 \%$ \\
\hline Wolsey & 4,688 & $74.5 \%$ & $20.9 \%$ & $4.6 \%$ & 14,396 & $33.3 \%$ & $26.1 \%$ & $40.6 \%$ \\
\hline Average & & $42.2 \%$ & $12.6 \%$ & $45.2 \%$ & & $28.2 \%$ & $20.6 \%$ & $51.2 \%$ \\
\hline
\end{tabular}

Total compensation and components of total compensation for Total Board Pay variable for two separate years: 2000 and 2006. Components of total compensation include: All non-incentive pay (salaries and pension contributions); Non-equity incentive pay (bonuses); and Equity incentive pay (options and LTIPS)

Source: BoardEx

Exhibit 2: Growth in Nominal Pay Across Executives, Managers and All Employees 1997-2006

\begin{tabular}{lll}
\hline Pay Group & Annualised & Total \\
& Nominal & Nominal \\
& Mean Pay & Mean Pay \\
& Growth & Growth \\
& $1997-2006$ & $1997-2006$ \\
\hline Total Board Pay & $6.77 \%$ & $80.41 \%$ \\
Highest Paid Director & $9.79 \%$ & $131.78 \%$ \\
Managers and Senior Officials & $4.63 \%$ & $50.26 \%$ \\
All Employees & $3.92 \%$ & $41.38 \%$ \\
\hline
\end{tabular}

Comparison of growth in mean real cash compensation of the total board and highest paid director with managers and all employees from Annual Survey of Hours and Earnings (ASHES).

Source: Datastream and www.statistics.gov.uk. 


\begin{tabular}{lllrrr}
\hline $\begin{array}{l}\text { Industry } \\
\text { Code }\end{array}$ & Industry Group & $\begin{array}{l}\text { Total } \\
\text { Pay } \\
\left(£^{\prime} 000\right)\end{array}$ & Rank & $\begin{array}{l}\text { Highest } \\
\text { Paid } \\
\text { Director } \\
\left(£^{\prime} 000\right)\end{array}$ & Rank \\
1 & Resources & $3,321.20$ & 3 & 890.09 & 3 \\
2 & Basic Industries & $2,325.13$ & 6 & 652.49 & 7 \\
3 & General Industrials & $1,973.73$ & 9 & 617.62 & 8 \\
4 & Cyclical Consumer Goods & $2,567.39$ & 5 & 792.16 & 5 \\
5 & Non-cyclical Con. Goods & $2,787.18$ & 4 & 805.41 & 4 \\
6 & Cyclical Service & $2,269.45$ & 7 & 723.34 & 6 \\
7 & Non-cyclical Services & $3,848.35$ & 1 & 954.92 & 1 \\
8 & Utilities & $2,002.92$ & 8 & 570.31 & 9 \\
9 & Financials & $3,544.80$ & 2 & 915.88 & 2 \\
10 & Information Technology & $1,383.58$ & 10 & 439.32 & 10 \\
Total & & $2,528.92$ & & 733.79 & \\
\hline
\end{tabular}

Real total board pay and pay of highest paid director by ten broad industry groups.

Exhibit 4: Time Dummy coefficients

\begin{tabular}{crr}
\hline $\begin{array}{c}\text { Fiscal } \\
\text { Year }\end{array}$ & $\begin{array}{c}\text { Total Board } \\
\text { Pay }\end{array}$ & $\begin{array}{c}\text { Highest } \\
\text { Paid } \\
\text { Director } \\
\text { Pay }\end{array}$ \\
\hline $1995 / 96$ & 0.0239 & 0.0703 \\
& {$[0.023]$} & {$[0.028]^{*}$} \\
$1996 / 97$ & 0.0792 & 0.1324 \\
& {$[0.023]^{* *}$} & {$[0.027]^{* *}$} \\
$1997 / 98$ & 0.101 & 0.1909 \\
& {$[0.023]^{* *}$} & {$[0.028]^{* *}$} \\
$1998 / 99$ & 0.1037 & 0.1965 \\
& {$[0.023]^{* *}$} & {$[0.028]^{* *}$} \\
$1999 / 00$ & 0.1787 & 0.2889 \\
& {$[0.024]^{* *}$} & {$[0.029]^{* *}$} \\
$2000 / 01$ & 0.2404 & 0.3487 \\
& {$[0.025]^{* *}$} & {$[0.030]^{* *}$} \\
$2001 / 02$ & 0.2745 & 0.3906 \\
& {$[0.025]^{* *}$} & {$[0.030]^{* *}$} \\
$2002 / 03$ & 0.3176 & 0.4588 \\
& {$[0.026]^{* *}$} & {$[0.031]^{* *}$} \\
$2003 / 04$ & 0.3117 & 0.4382 \\
& {$[0.027]^{* *}$} & {$[0.032]^{* *}$} \\
$2004 / 05$ & 0.3663 & 0.5145 \\
& {$[0.027]^{* *}$} & {$[0.033]^{* *}$} \\
$2005 / 06$ & 0.3999 & 0.5989 \\
& {$[0.041]^{* *}$} & {$[0.049]^{* *}$} \\
\hline
\end{tabular}

Time dummy coefficients from fixed effects regression model (2) in Table 2 and Table 3. Year 1994/95 is the reference year. Standard errors in brackets. * denotes significant at 5\%; ** denotes significant at $1 \%$; 


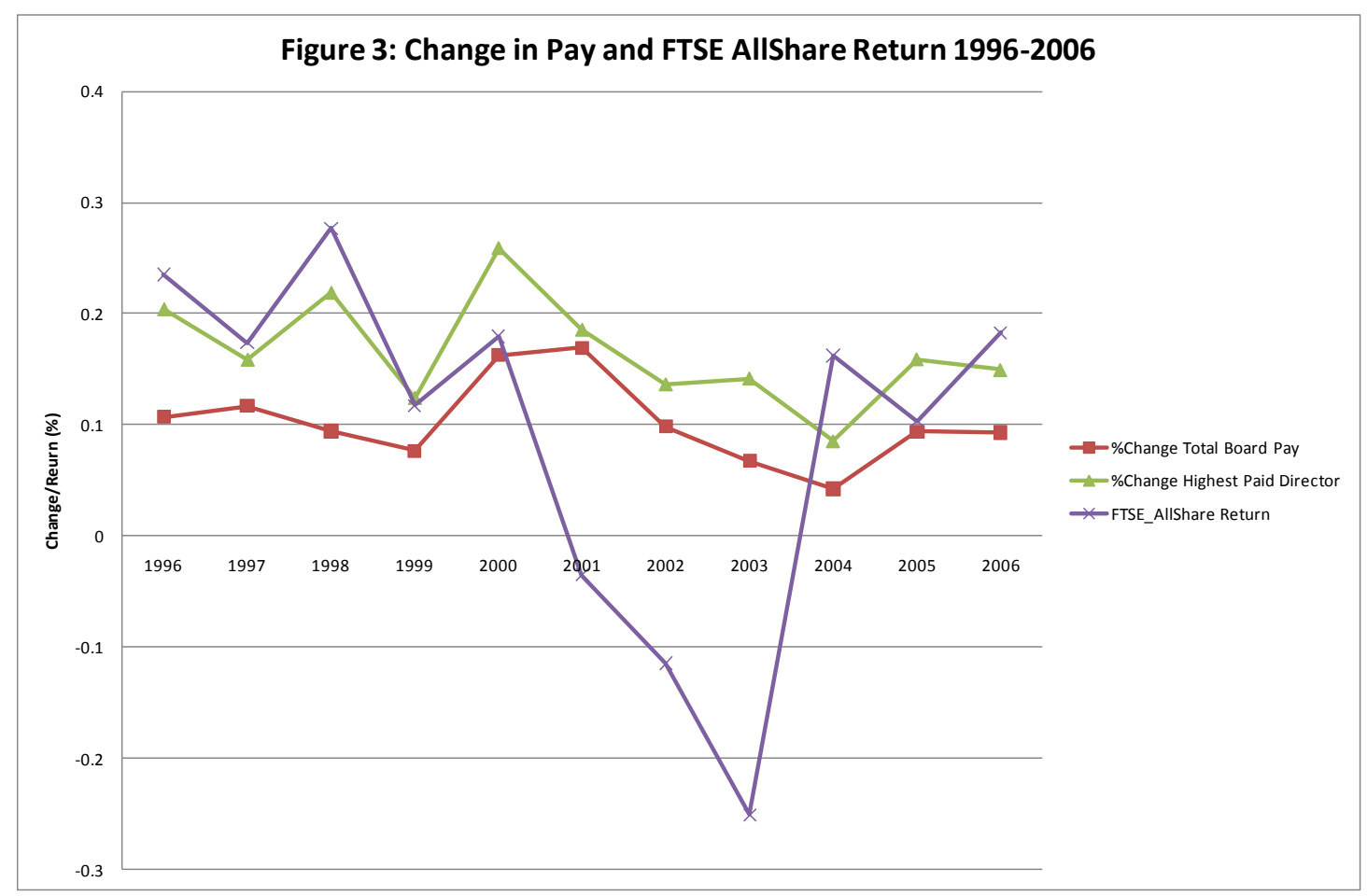

Fig. 3. A comparison of the percentage changes in both pay variables and the total return of the FTSE All Share index 1995/96-2005/06, pay is cash compensation (salary, bonus and pension contributions) and is adjusted to 2001/02 fiscal year prices.

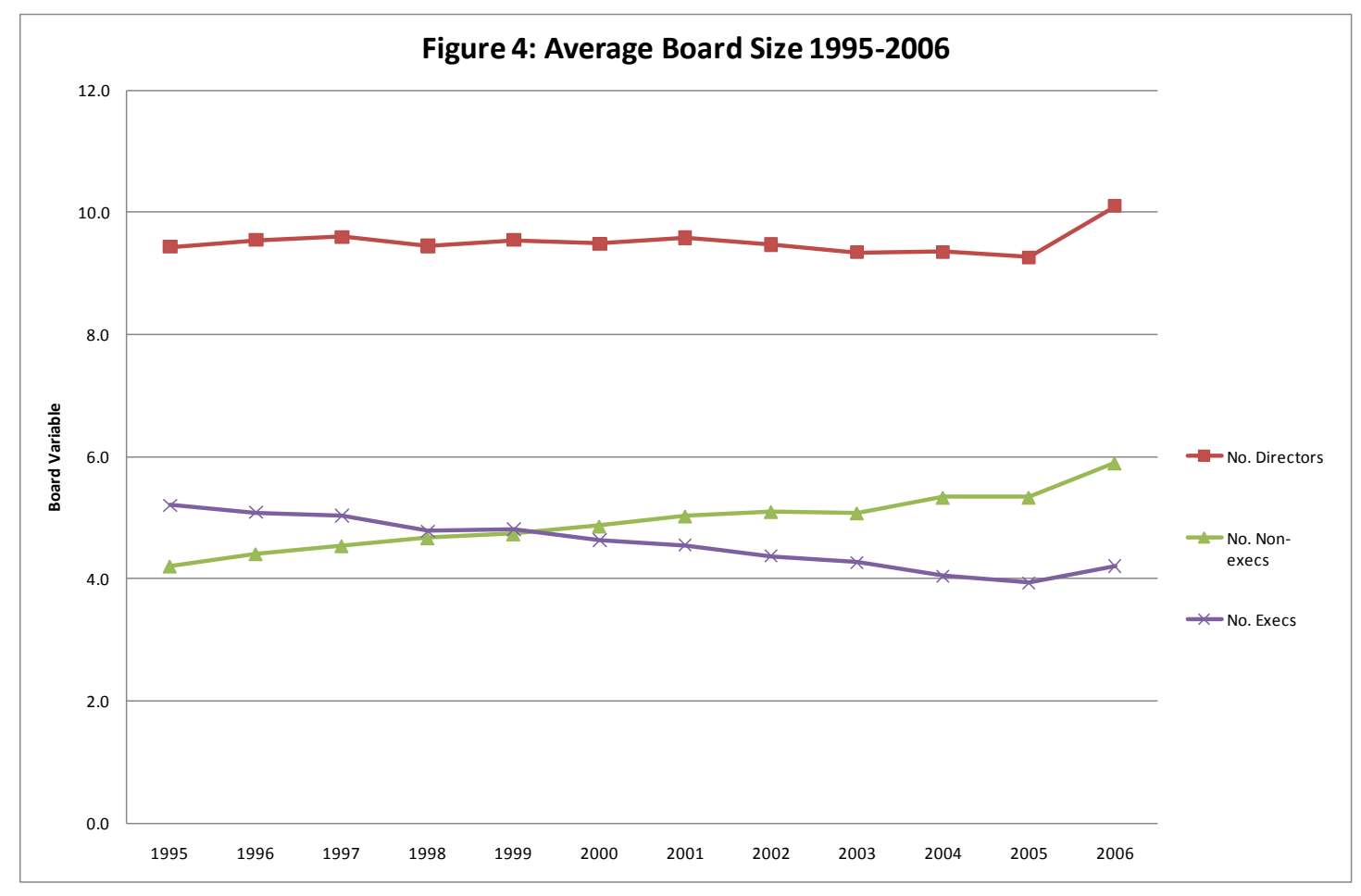

Fig. 4. Average board size, number of executives and number of non-executives 1994/95-2005/06. 


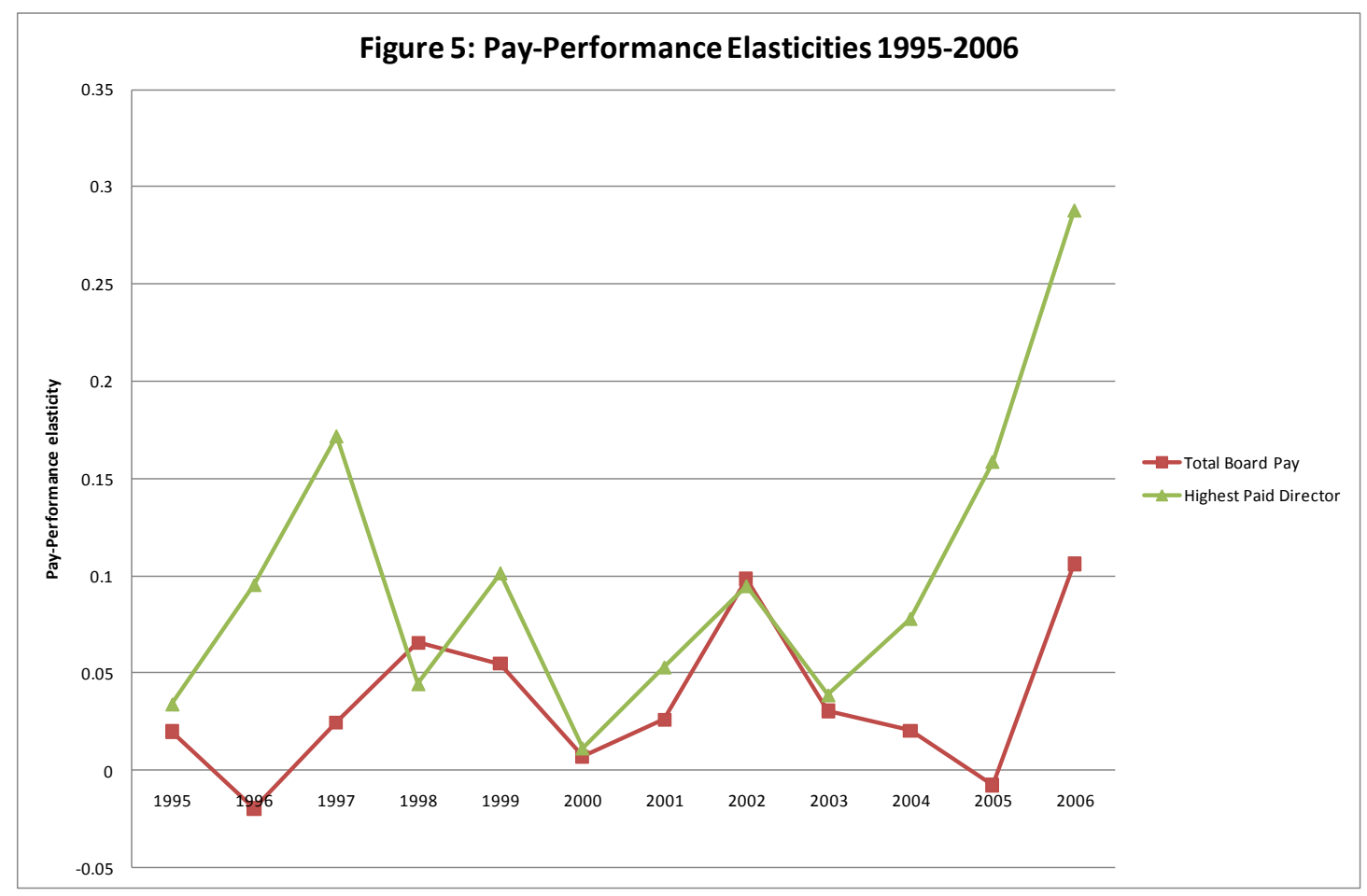

Fig. 5. Pay performance elasticities 1994/1995-2005/06 obtained from fixed effects regressions.. Pay is cash compensation (salary and bonuses) and is adjusted to 2005/06 fiscal year prices. Performance is measured by total shareholder return.

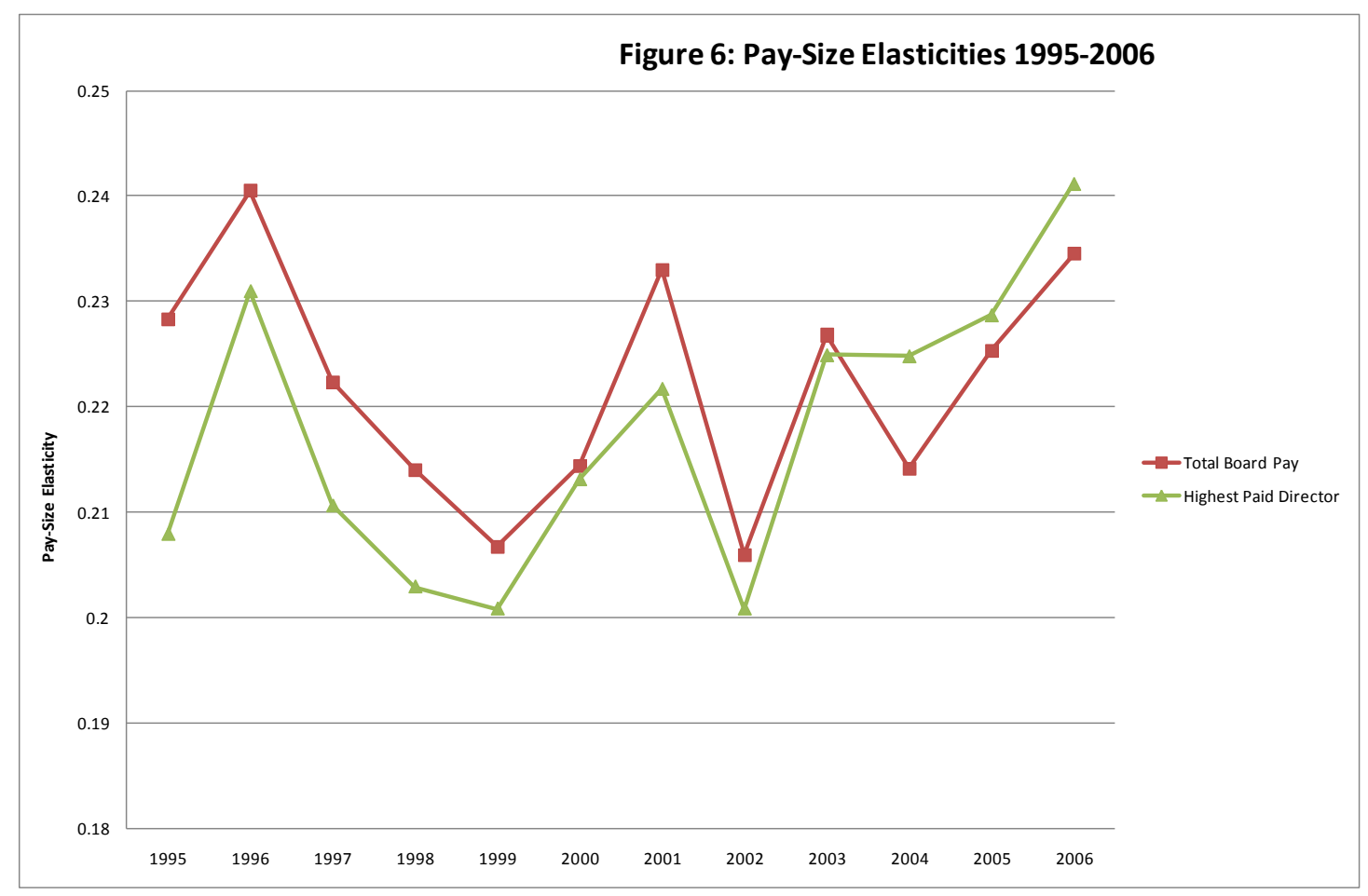

Fig 6. Pay size elasticities 1994/95-2001/06 obtained from fixed effects regressions. Pay is cash compensation (salary and bonuses) and size is measured by total assets. Both pay and assets are adjusted to 2005/06 fiscal year prices. 


\section{Appendix 1: List of Variables}

\begin{tabular}{|c|c|}
\hline Accounting Year & $\begin{array}{l}\text { Individual firms accounting year as given by the year ends from } \\
\text { Datastream }\end{array}$ \\
\hline Fiscal Year 1995-2006 & $\begin{array}{l}\text { Set of fiscal years which firm's account year is matched up with - used as } \\
\text { year dummy variables in regressions }\end{array}$ \\
\hline FTSE Index & $\begin{array}{l}\text { Index that company was constituent of at the end of the firm's accounting } \\
\text { year - FTSE 100, FTSE 250, FTSE small cap, FTSE fledgling or FTSE } \\
\text { aim }\end{array}$ \\
\hline Indgroup1-10 & A set of 10 sector groups defined in Appendix 3 \\
\hline Market Capitalisation & $\begin{array}{l}\text { Market capitalisation of the firm at the end of the accounting year }-£ m \\
\text { (source: Hemscott trading dataset) }\end{array}$ \\
\hline Total Assets & Total assets of firm $-£^{\prime} 000$ (Datastream code 392 ) \\
\hline Total Board Pay & Total pay of all directors of the firm board - $£^{\prime} 000$ (Datastream code 126) \\
\hline Highest Paid Director Pay & Remuneration of the highest paid director - £'000 (Datastream code 244) \\
\hline Firm Return & $\begin{array}{l}\text { Individual firm's raw stock market return by accounting year (source: } \\
\text { Hemscott trading dataset) }\end{array}$ \\
\hline FTSE All Share Return & $\begin{array}{l}\text { Total annual return of FTSE All share index by firm's accounting year } \\
\text { (Datastream) }\end{array}$ \\
\hline Firm market adjusted return & $\begin{array}{l}\text { Firm's abnormal return for its accounting year using expected returns from } \\
\text { CAPM model }\end{array}$ \\
\hline Firm industry adjusted return & $\begin{array}{l}\text { Firm's abnormal return for its accounting year using expected returns from } \\
\text { Industry CAPM model }\end{array}$ \\
\hline No. of Directors & $\begin{array}{l}\text { Total number of directors in the firm in the accounting year (Datastream } \\
\text { code 242) }\end{array}$ \\
\hline No. of non-executives & $\begin{array}{l}\text { Number of non-executive directors in the firms accounting year } \\
\text { (Datastream code 243) }\end{array}$ \\
\hline$\%$ of non-executives & Proportion of board who are non-executive directors, \\
\hline Pre-tax profit & Firm's pre-tax profits - £'000 (Datastream code 154) \\
\hline Net EPS & Firm's net earnings per share - pence (Datastream code 254) \\
\hline $\begin{array}{l}\text { Standard Deviation } \\
\text { Returns }\end{array}$ & Standard deviation of firm's daily return based on previous accounting year \\
\hline
\end{tabular}




\section{Appendix 2: Characteristics of Sample}

Panel A: Construction of Sample

Total Population of FTSE350 stocks during 1994-2006 776

Less unavailable data ( \& Inv. Trusts) 72

\begin{tabular}{|l|r|}
\hline Less firms with less than 3 years data & 289 \\
\hline
\end{tabular}

Firms in sample 415

Panel B: Number of Firms per Year

\begin{tabular}{|l|r|}
\hline Account Year & $\begin{array}{l}\text { Number of } \\
\text { Firms }\end{array}$ \\
\hline $1994 / 95$ & 267 \\
\hline $1995 / 96$ & 343 \\
\hline $1996 / 97$ & 361 \\
\hline $1997 / 98$ & 377 \\
\hline $1998 / 99$ & 380 \\
\hline $1999 / 00$ & 371 \\
\hline $2000 / 01$ & 353 \\
\hline $2001 / 02$ & 347 \\
\hline $2002 / 03$ & 316 \\
\hline $2003 / 04$ & 314 \\
\hline $2004 / 05$ & 314 \\
\hline $2005 / 06$ & 300 \\
\hline
\end{tabular}

Panel C: Distribution of the number of observations per firm

\begin{tabular}{|c|c|c|}
\hline $\begin{array}{l}\text { No. of } \\
\text { Account } \\
\text { Years }\end{array}$ & Freq. & Percent \\
\hline & 3 & 1.2 \\
\hline & 1 & 4.3 \\
\hline & 2 & 5.1 \\
\hline & 2 & 6.3 \\
\hline & 2 & 5.1 \\
\hline & 4 & 10.1 \\
\hline & 1 & 4.3 \\
\hline 1 & 2 & 4.8 \\
\hline 1 & 7 & 18.6 \\
\hline 1 & 16 & 40.2 \\
\hline Total & 41 & 100 \\
\hline
\end{tabular}




\section{Appendix 3: Industry/Sector Groups}

\begin{tabular}{|l|l|r|}
\hline $\begin{array}{l}\text { Industry } \\
\text { Group }\end{array}$ & \multicolumn{1}{|c|}{ FTSE Actuaries definitions of industry sectors } & \multicolumn{1}{|c|}{$\begin{array}{l}\text { Number } \\
\text { of firms }\end{array}$} \\
\hline 1 & Resources (Including Mining, Oil \& Gas) & 14 \\
\hline 2 & Basic Industries (Chemicals, Construction, Forestry, Steel) & 52 \\
\hline 3 & $\begin{array}{l}\text { General Industrials (Aerospace, diversified industrials, Electronic \& } \\
\text { Electrical, Engineering) }\end{array}$ & 49 \\
\hline 4 & $\begin{array}{l}\text { Cyclical Consumer Goods (Automobiles, Household Goods \& } \\
\text { Textiles) }\end{array}$ & 6 \\
\hline 5 & $\begin{array}{l}\text { Non-cyclical Consumer Goods (Beverages, Food, Health, Personal } \\
\text { Care, Pharmaceuticals, Tobacco) }\end{array}$ & 45 \\
\hline 6 & $\begin{array}{l}\text { Cyclical Services (General retailers, Leisure, Media, Support } \\
\text { Services, Transport) }\end{array}$ & 132 \\
\hline 7 & $\begin{array}{l}\text { Non-cyclical Services (Food \& drug Retailers, } \\
\text { Telecommunications) }\end{array}$ \\
\hline 8 & Utilities (Electricity, Gas, Water) & 16 \\
\hline 9 & Financials (Banks, Insurance, Real Estate, speciality Finance) & 20 \\
\hline 10 & $\begin{array}{l}\text { Information Technology (IT Hardware, IT Software \& Computer } \\
\text { Services) }\end{array}$ & 22 \\
\hline All & \multicolumn{1}{|l}{} & 415 \\
\hline
\end{tabular}




\section{REFERENCES}

Adams, R. (2009), 'Governance and the financial crisis', in Thomsen, S., Rose, C. and Risager, O. (Eds.), Understanding the Financial Crisis: Investment, Risk and Governance (pp. 156-175) Copenhagen, Denmark: SimCorp StrategyLab.

Aggarwal, R and Samwick, A. (1999), 'The Other Side if the Trade-off: The Impact of Risk on Executive Compensation', Journal of Political Economy, 107, 65-104.

Beltratti,A. and R. M. Stulz, (2010), 'The Credit Crisis Around the Globe: Why Did Some Banks Perform Better?' Dice Center Working Paper No. 2010-05 Fisher College of Business.

Beltratti, A. and R. Stulz, (2009), 'Why Did Some Banks Perform Better During the Credit Crisis? A Cross-Country Study of the Impact of Governance and Regulation', Working paper, Bocconi University and The Ohio State University

Benito, A and M. Conyon (1999), 'The Governance of Directors' Pay from UK Companies', Journal of Management and Governance, 3, 117-136.

Bertrand, M and S. Mullainathan (2001), 'Are CEO's rewarded for luck? The Ones Without Principals Are’, Quarterly Journal of Economics, 901-932.

Buck, T., A. Bruce, B.G.M. Main and H. Udueni (2003) 'Long Term Incentive plans, Executive Pay and UK Company Performance', Journal of Management Studies, 40, 1709-1727.

Carter, M.E., L.J. Lynch, and V. Zamora (2009), 'The Americanization of CEO Pay in European Firms', Boston College Working Paper

Committee of European Banking Supervisors (2009). High-level Principles for Remuneration Policies (Rem. HLP), April

Committee of European Banking Supervisors (2010), 'Consultation Paper on Guidelines on Remuneration Policies and Practices', Consultation Paper, no. CP42

Conyon, M. (1997), 'Corporate Governance and Executive Compensation', International Journal of Industrial Organisation, 15, 493-509.

Conyon, M., P. Gregg and S. Machin (1995), 'Taking care of business: Executive Compensation in the United Kingdom', Economic Journal, 105, 704-714.

Conyon, M and Murphy, K. (2000), 'The Prince and The Pauper? CEO Pay in The United States and United Kingdom', Economic Journal, 110, 640-671.

Conyon, M.J., N. Fernandes, M. A. Ferreira, P. Matos and K.J. Murphy (2010), 'The Executive Compensation Controversy: A Transatlantic Analysis', redraft of Annual FRDB conference paper. 
Core, J., and D. Larcker (1999), 'Corporate Governance, chief executive officer

compensation, and firm performance', Journal of Financial Economics, 51(3), 371-406.

European Commission (2009), Proposal for a DIRECTIVE OF THE EUROPEAN PARLIAMENT AND OF THE COUNCIL amending Directives 2006/48/EC and 2006/49/EC as regards capital requirements for the trading book and for resecuritisations, and the supervisory review of remuneration policies, July.

Erkens, D., M. Hung and P. Matos (2009), 'Corporate Governance in the 2007-2008 Financial Crisis: Evidence from Financial Institutions Worldwide', University of Southern California Working Paper, August 2009.

Fahlenbrach, R. and R. M. Stulz (2010), 'Bank CEO incentives and the credit crisis', Journal of Financial Economics, forthcoming

Fernandes, N. , M. A. Ferreira, P. Matos, and K. J. Murphy (2010), 'The Pay Divide: (Why) Are U.S. Top Executives Paid More?', ECGI Finance Working Paper $\mathrm{N}^{\circ}$. 255/2009 (updated December 2010).

Financial Stability Forum (2009), Principles for Sound Compensation Practices, 2 April 2009.

Financial Services Authority (2009a), Reforming remuneration practices in financial services, Consultation Paper, 09/10 March.

Financial Services Authority (2009b). Reforming remuneration practices in financial services: Feedback on CP09/10 and final rules, Policy Statement 09/15, August.

Financial Services Authority (2010), Revising the remuneration code: Feedback on CP10/19 and final rules, Policy Statement 10/20, December.

Garen, J. (1994), 'Executive Compensation and Principal-Agent Theory', Journal of Political Economy, 102 (6), 1175-1199.

Garvey, G and T. Milbourn (2003), 'Incentive Compensation when executives can hedge the market: Evidence of Relative Performance Evaluation in the Cross Section', Journal of Finance, 58, 4, 1557-1581.

Gibbons, R., and K.J. Murphy (1990), 'Relative performance evaluation for Chief Executive Officers', Industrial and Labour Relations Review, 43 (3), 30-51.

Girma, S., S. Thompson, and P. Wright (2007), 'Corporate Governance Reforms and Executive Compensation Determination: Evidence from the UK', The Manchester School, 75 (1), 65-81. 
Gregg, P., S. Machin and S Symanski (1993), 'The disappearing relationship between directors' pay and corporate performance', British Journal of Industrial Relations 31 (1), (March), 1-10.

Hall B., and J. Liebman (1998), 'Are CEO's really paid like Bureaucrats?', The Quarterly Journal of Economics, 113 (30), 653-691.

Jensen, M., and K.J. Murphy (1990), 'Performance pay and top management incentives', Journal of Political Economy, 98, 225-264.

Main, B.G.M., A. Bruce, and T. Buck (1996), 'Total Board Remuneration and Company Performance', Economic Journal, 106, 1627-1644.

Murphy, K. (1999), 'Executive Compensation', in O. Ashenfelter and D. Card.(eds) Handbook of Labour Economics, vol.3. Amsterdam: North Holland, 2485-2563.

Ozkan, N., (2011), 'CEO Compensation and Firm Performance: an Empirical Investigation of UK Panel Data', European Financial Management, forthcoming.

Renneboog, L., and G. Trojanowski, (2010) "Managerial Remuneration and Disciplining in the UK: A Tale of Two Governance Regimes” ECGI - Finance Working Paper No. $301 / 2010$.

Turnbull, N. (1999), Internal Control: Guidance for Directors on the Combined Code, (London Stock Exchange).

Turner, A. (2009), A regulatory response to the global banking crisis, March (Financial Services Authority).

Walker, D. (2009a), A review of corporate governance in UK banks and other financial industry entities, (Financial Services Authority) July.

Walker, D., (2009b), A review of corporate governance in UK banks and other financial industry entities: final recommendations, (Financial Services Authority) November. 